\title{
PIPs in Neurological Diseases
}

Author: Mark G. Waugh

Address: $\quad$ Lipid and Membrane Biology Group

Institute for Liver and Digestive Health,

UCL,

Royal Free Campus,

Rowland Hill Street

London

NW3 2PF

United Kingdom

E-Mail: $\quad$ m.waugh@ucl.ac.uk

Abbreviations: $A \beta$ - amyloid $\beta$ protein; CMT - Charcot-Marie-Tooth, GPCR - G protein-coupled receptor; PICALM - phosphatidylinositol binding clathrin assembly protein; PIPs - phosphoinositides, PI3K - phosphoinositide 3-kinase; PI4K - phosphatidylinositol 4-kinase; PLC - phospholipase C; PH domain - pleckstrin homology domain, PIPK - PI4P 5-kinase. 
Acknowledgements: I acknowledge funding from the Royal Free Charity and helpful comments from David Brown, Shane Minogue and K. M .Emily Chu.

Conflict of interest statement: The author declares no conflict of interest. 


\section{Abstract}

Phosphoinositide (PIP) lipids regulate many aspects of cell function in the nervous system including receptor signalling, secretion, endocytosis, migration and survival. Levels of PIPs such as PI4P, $\mathrm{PI}(4,5) \mathrm{P}_{2}$ and $\mathrm{PI}(3,4,5) \mathrm{P}_{3}$ are normally tightly regulated by phosphoinositide kinases and phosphatases. Deregulation of these biochemical pathways leads to lipid imbalances, usually on intracellular endosomal membranes, and these changes have been linked to a number of major neurological diseases including Alzheimer's, Parkinson's, epilepsy, stroke, cancer and a range of rarer inherited disorders including brain overgrowth syndromes, Charcot-Marie-Tooth neuropathies and neurodevelopmental conditions such as Lowe's syndrome. This article analyses recent progress in this area and explains how PIP lipids are involved, to varying degrees, in almost every class of neurological disease.

Keywords: Phosphatidylinositol; lipid; disease; brain; endosome; membrane. 
Table of contents:

1.0 Introduction

1.1 Signalling by $\mathrm{PI} 4 \mathrm{P}$ and $\mathrm{PI}(4,5) \mathrm{P}_{2}$

1.2 PI 4-kinases in the CNS

1.3 Generation of $\mathrm{PI}(4,5) \mathrm{P}_{2}$ in the brain

1.4 PIP 5-kinase mutations in neurological diseases

2.0 The channelopathies and disorders of PIP binding

2.1 Role of PIP protein binding domains in neurological diseases

3.0 CNS disorders caused by PI4P and PI(4,5) $\mathrm{P}_{2}$ imbalances

4.0 Defective PI 3-kinase signalling in neurological disease - overgrowth and myelination disorders

4.1 PI3K and Akt3 link brain overgrowth with epilepsy and autism

4.2 Neurological involvement in PTEN germline mutations and benign tumour growth

4.3 Activated PI3K signalling: overgrowth versus glioma

5.0 $\mathrm{PI}(3,5) \mathrm{P}_{2}$ and Charcot-Marie-Tooth neuropathies

5.1 Cilliopathies (Joubert's and MORM syndromes) and INPP5E

6.0 The emerging story of PIPs in Alzheimer's disease

6.1 Synaptojanin: a PIP link between Alzheimer's and Parkinson's diseases and epilepsy?

7.0 PIPs in stroke, exocitotoxic cell death and cerebral ischaemia

8.0 Conclusions 


\subsection{Introduction}

Phosphoinositides (PIPs) are structurally related and functionally diverse phospholipid molecules with many important roles in the nervous system. These functions include substrate supply to receptor-stimulated phospholipase C (PLC) and phosphoinositide 3-kinase (PI3K) signalling pathways, ion channel regulation, the control of intracellular vesicular trafficking, cytoskeletal organisation and protein-mediated inter-organelle lipid transport [1, 2]. Excluding the parent molecule phosphatidylinositol (PI) there are seven different lipids in the PIP family, consisting of PI4P, $\mathrm{PI}(4,5) \mathrm{P}_{2}, \mathrm{PI}(3,4,5) \mathrm{P}_{3}, \mathrm{PI}(3,4) \mathrm{P}_{2}, \mathrm{PI}(3,5) \mathrm{P}_{2}, \mathrm{PI} 3 \mathrm{P}$ and $\mathrm{PI5P}$. The different PIPs are formed by a collection of phosphoinositide kinase and phosphatases that catalyse the stepwise phosphorylation and dephosphorylation of hydroxyl groups on different positions of the inositol head group (Figure 1) [3]. In the nervous system, as in other mammalian tissues, the highest mass levels are for $\mathrm{PI}$, followed by $\mathrm{PI}$ P and $\mathrm{PI}(4,5) \mathrm{P}_{2}$, with much lower and often transient agonist-stimulated peaks of the D3phosphorylated lipids formed through receptor-activated phosphoinositide 3-kinase pathways[3].

\subsection{Signalling by $P I 4 P$ and $P I(4,5) P_{2}$}

Levels of $\mathrm{PI} 4 \mathrm{P}$ and $\mathrm{PI}(4,5) \mathrm{P}_{2}$ undergo rapid depletion and resynthesis following agonist activation of heterotrimeric $\mathrm{G}$ protein-coupled receptors (GPCRs) that signal through PLC $\beta$. PLC activation, usually initiated via $G \alpha_{q}$ subunits, induces substantial $\mathrm{PI}(4,5) \mathrm{P}_{2}$ hydrolysis and results in the formation of the second messengers inositol(1,4,5)-trisphosphate and diacylglycerol that mediate $\mathrm{Ca}^{2+}$ release from the endoplasmic reticulum and also PKC activation. GPCRs that signal through this route are highprofile drug targets in the treatment of neurological diseases. Examples include Alzheimer's disease where both orthosteric and allosteric ligands for the M1 muscarinic receptor [4] have been developed for the treatment of cognitive defects [5] and to inhibit the formation of neurofibrillary tangles and $\beta$-amyloid plaques [4, 6, 7]. Similarly, PLC-coupled delta opioid receptors are pharmacological candidates for chronic pain, epileptic seizures and locomotor disorders $[8,9]$. While GPCR-specific ligands and individual receptor expression patterns in the CNS facilitate the targeting 
of specific cell types and processes, drugs that inhibit PIP-metabolising enzymes also have some potential in the treatment of neurological diseases. Examples include the recent development of isoform-specific small molecule inhibitors of the $\mathrm{PI}(4,5) \mathrm{P}_{2}$-metabolising enzymes $\mathrm{PLC} \beta 3$ [10] and PIP5K1C [11] for the treatment of chronic pain.

\subsection{PI 4-kinases in the CNS}

Cellular PI4P levels are maintained by a family of four different PI 4-kinase (PI4K) enzymes: PI4K2A, PI4K2B, PI4KA and PI4KB (Figure 2). All four PI4K isozymes are expressed in the nervous system but they are targeted to different subcellular compartments including the trans-Golgi network (TGN), endosomes, secretory vesicles and the plasma membrane $[12,13]$. More recent work investigating the pathways that supply PI4P to plasma membrane signalling processes has revealed that multiple PI4K isoforms at different cellular locations are required to maintain the signalling pools of PI4P and $\mathrm{PI}(4,5) \mathrm{P}_{2}[14,15] . \mathrm{PI} 4 \mathrm{~K} 2 \mathrm{~A}$, the crystal structure of which has been solved $[16,17]$, is by far the most abundant PI kinase activity measurable in brain membranes [18] and has been implicated in TGNendosomal sorting [19-24] and cell survival [18]. However, non-neuronal studies indicate that the wortmannin-sensitive PI4KA is likely to be the dominant isozyme for synthesizing the PI4P required for agonist-dependent signalling $[25,26]$.

When considering the role of any PIP pathway in neurological disease it is important to note that each phosphoinositide-metabolising enzyme appears to possess a distinct protein interactome that operates in combination with catalytic activity to define its overall function in neuronal signalling and trafficking [13]. A well-studied example to illustrate these layers of complexity is PI4K2A, which synthesises a pool of PI4P on TGN and endosomal membranes, and which has also been visualised on secretory vesicles $[22,23,27-32]$. This enzyme contains an amino acid motif that can bind the E3 ubiquitin ligase itch and this interaction facilitates reciprocal regulation of both enzymes' catalytic activities [33]. This intermolecular association thereby functionally associates rates of endosomal 
ubiquitination with membrane PI4P synthesis, and PI4P-dependent signalling and trafficking with protein targeting for degradation.

In addition to effects on protein ubiquitination, the modular protein-binding functions of PI4K2A influence membrane sorting in TGN endosomal trafficking. PI4K2A contains a dileucine AP-3 clathrin adaptor-binding motif that partly mediates non-catalytic PI4K2A functions in cargo sorting and trafficking from the TGN to late endosomes [19]. Furthermore, PI4K2A has been shown in crosslinking and proteomic studies to be a component of the multi-protein, biogenesis of lysosomerelated organelles complex-1 (BLOC-1) and also the Wiskott Aldrich Syndrome protein and scar homologue (WASH) complex that regulates the actin cytoskeleton [34]. In addition, PI4K2A has been shown to be a protein-binding partner for the R-SNARE protein VAMP3 [24]. Therefore, it is likely that alterations to PI4K2A expression can have ramifications for the numerous components of its associated protein interaction network and that these, in turn, can impact on the multiple neuronal roles that have been ascribed to this protein [20,34-38]. There is also evidence for PI4K2A activation by the transcription factor c-FOS, which represents a novel avenue for research and potentially links alterations to PI4P synthesis with genomic transcriptional regulation $[39,40]$.

In conjunction with a repertoire of protein binding partners, post-translational modifications of PI4K2A are important for its intracellular trafficking functions. Recently, PI4K2A has been shown to be phosphorylated by GSK3 and this regulates PI4K2A-dependent trafficking of AMPA receptors by promoting the binding of the AP-3 clathrin adaptor [41]. The catalytic activity of PI4K2A is also regulated by post-translational modification. The rate of PI4P synthesis by PI4K2A is determined by non-covalent membrane interactions and the palmitoylation of two cysteine residues within the catalytic domain of the protein [42-45]. The membrane lipid environment and particularly the cholesterol content of these membranes can affect the enzyme's catalytic activity $[27,46-48]$ and palmitoylation state, since the late Golgi-localised palmitoyl transferases that modify PI4K2A are also cholesterol sensitive [45]. Targeting of PI4K2A to cholesterol-rich membranes is also important for 
its proposed role in regulating OSBP-dependent sphingomyelin synthesis at this subcellular location [49]. Hence, PI4K2A is an example of a single PI-utilising enzyme that integrates a membrane environment-sensitive catalytic function with a diverse range of non-catalytic functions that include protein targeting for degradation, endosomal trafficking and non-vesicular lipid transport, all of which are relevant to PIP disease pathways in the CNS.

\subsection{Generation of $P I(4,5) P_{2}$ in the brain}

Resynthesis of $\mathrm{PI}(4,5) \mathrm{P}_{2}$ requires $\mathrm{PI4P}$ 5-kinase activity by three main isozymes, PIPK1A, PIPK1B and PIPK1C (Figure 2). While evidence demonstrates that PIPK1A negatively regulates neurite outgrowth [50] and PIPK1B growth cone morphology [51], in the CNS at least, isoform-specific knockout studies in mice have revealed a dominant role for PIPK1C isozymes in $\mathrm{PI}(4,5) \mathrm{P}_{2}$ generation $[11,52,53]$. $\mathrm{PI}(4,5) \mathrm{P}_{2}$ can also be generated through the D4 phosphorylation of PI5P by PI5P 4-kinases [54]. PI5P can be synthesised by D5 phosphorylation of PI by PIKfyve (also known as Fab1) [55-57], but there is strong recent evidence that in cells $\mathrm{PIKfyve}$ phosphorylates $\mathrm{PI} \mathrm{P}$ to $\mathrm{PI}(3,5) \mathrm{P}_{2}$, which is then dephosphorylated via 3-phosphatase activity to generate PI5P [58]. PI5P is a much less abundant lipid substrate than PI4P and hence, PI5P is a not the major source of cellular PI(4,5) $\mathrm{P}_{2}$ in the brain.

\subsection{PIP 5-kinase mutations in neurological diseases}

To date, there is only one direct example of a genetic mutation in either a PI4K or PIP 5-kinase causing a human disease and that is PIP5K1C in the rare autosomal recessive disorder lethal muscle contractural syndrome type 3 [59]. However, there has been an interesting development recently concerning the possible involvement of PIP5K1B in Friedreich's ataxia [60], a multisystem disease that features pronounced neurodegeneration. The PIPK1B gene had previously been implicated as the cause of this disorder but subsequent papers revealed that this was probably a misidentification and concluded instead that Friedreich's ataxia was due to silencing of the FTX gene which encodes the mitochondrial protein frataxin $[61,62]$. However, Bayot and colleagues [60] have reported that 
the GGA triplet repeat expansion that silences frataxin gene also results in cis-silencing of PIPK1B, leading to diminished $\mathrm{PI}(4,5) \mathrm{P}_{2}$ production and striking disorganisation of the actin cytoskeleton [60]. These observations indicate that genetic impairment of PIPK1B function could contribute to some of the complicated clinical presentations of this ataxia.

\subsection{The channelopathies and disorders of PIP binding}

In addition to their roles in substrate supply to the PLC and PI3K signalling pathways [63], D4phosphorylated PIPs have important roles in ion channel regulation at the plasma membrane [15, 64-79]. Lipids such as $\mathrm{PI}(4,5) \mathrm{P}_{2}$ and $\mathrm{PI} 4 \mathrm{P}$ can either positively or negatively [80] influence ion flux. This occurs through interactions with specific sites on channel proteins or through effects on membrane charge, and frequently in tandem with other modulators such as heterotrimeric $G$ proteins subunits or subunit phosphorylation $[73,74,81-83]$. This lipid-based regulatory mode is relevant to neurological diseases since important pharmacological targets, for example, the KCNQ channel in epilepsy, are regulated by membrane PIP levels [76]. Furthermore, dysfunctional channelPIP interactions, usually due to genetic mutations affecting channel protein structure, lead to deregulated neuronal transmission. Diseases that feature this type of molecular mechanism are often collectively referred to as channelopathies.

One well-established example of a channelopathy involving PIPs is a potassium-sensitive periodic paralysis with associated ventricular arrhythmias known as Andersen-Tawil syndrome [84-87]. This can be either an autosomal recessive disorder or occur sporadically and is caused by point mutations in PIP interaction sites on the KCNJ2 (Kir2.1) inwardly-rectifying potassium channel. Interestingly, while $\mathrm{PI}(4,5) \mathrm{P}_{2}$ activates $\mathrm{KCNJ} 2$ opening the binding of other membrane PIP species inhibit this process by directly competing out $\mathrm{PI}(4,5) \mathrm{P}_{2}$ binding [88]. Structural analysis of the protein family has revealed the presence of two distinct PIP interaction sites on the channel protein. The first PIP interaction site consists of a conserved non-specific phospholipid-binding region in the 
transmembrane domain and a second site, located in the channel's cytoplasmic tail, specifically binds $\mathrm{PI}(4,5) \mathrm{P}_{2}$ [89]. Conversely, for potassium channels such the TRPV4 that are negatively regulated by $\mathrm{PI}(4,5) \mathrm{P}_{2}$ binding, in this case via lipid biding to an ankyrin homology domain, mutations of the PIP interaction site result in augmented channel function [80], and this is relevant to TRPV4 channelopathies such as Charcot-Marie-Tooth (CMT) type $2 \mathrm{C}$ and congenital distal and scapuloperoneal spinal muscular atrophy [80, 90-93].

Another corollary of these recent insights is that the intramembrane balance of $\mathrm{PI} 4 \mathrm{P}$ and $\mathrm{PI}(4,5) \mathrm{P}_{2}$ is likely to be an important determinant of ion channel gating. Furthermore, distortions of this ratio, as can occur in inherited conditions characterised by $\mathrm{PI}(4,5) \mathrm{P}_{2}$ phosphatase dysfunction, may be sufficient to cause ion channel deregulation $[94,95]$. However, this is hitherto an underexplored area of neurological research. It is also important to mention that PIPs can influence ionotropic neurotransmission through vesicular trafficking processes that deliver, recycle and degrade plasma membrane-localised receptors, channels [13] and neurotransmitter transporter proteins [96]. These PIP-dependent processes have repercussions for receptor reserve and thus agonist efficacy, and collectively represent another route through which PIPs can modulate synaptic signalling.

While much attention has focused on $\mathrm{K}^{+}$channel regulation by PIPs, there is also a role for D3phosphorylated PIPs in this aspect of neurophysiology [97]. The best studied disease in this regard is mucolipidosis type IV, an autosomal recessive neurodegenerative disorder that can be caused by mutations in the $\mathrm{PI}(3,5) \mathrm{P}_{2}$ interaction site on the TRPML1 channel, which localises to intracellular late endosomal/lysosomal membranes where it mediates metal cation efflux [98-100]. Significantly, a recent publication has described the development of small molecule activators of TRPML1 that can restore the function of $\mathrm{PI}(3,5) \mathrm{P}_{2}$-insensitive structural variants that are also associated with the mucolipidosis phenotype [101]. This report sets an important precedent and indicates that molecules targeting PIP-channel interactions may be an important area for future drug development in neurodegenerative diseases. 


\subsection{Role of PIP protein binding domains in neurological diseases}

A recent proteomics study identified 405 PIP-interacting proteins, which unexpectedly means that this set of proteins is more numerous than the entire complement of proteins involved in either phosphoprotein or ubiquitin binding [102]. PIPs can influence a wide range of processes in neurons through the membrane recruitment of proteins containing either $\mathrm{PI} 4 \mathrm{P}$ - or $\mathrm{PI}(4,5) \mathrm{P}_{2}$-binding domains such as the PIP-specific pleckstrin homology (PH) domains, epsin N-terminal homology (ENTH) and AP180 N-terminal homology (ANTH) domains, and PX and FYVE domains [103]. These specific intermolecular interactions facilitate the spatial and temporal targeting of signalling proteins such as PLC $\gamma$ and Akt during agonist-stimulated PIP signalling, and also the recruitment of membrane trafficking machinery such as epsin-1, AP-2, AP180 and dynamin to the plasma membrane for clathrinmediated coated pit formation and endocytosis.

$\mathrm{PI} 4 \mathrm{P}$ has an important role in targeting, via PH domain binding, lipid transfer proteins such as OSBP, CERT and FAAP2 to PI4P-enriched membranes at points of inter-organelle contact sites (reviewed in [13]). Furthermore, the recent finding that PI4P hydrolysis by Sac1 phosphatase releases energy to facilitate non-vesicular cholesterol transfer at Golgi-endoplasmic reticulum contact sites suggests an additional role for PIPs as a membrane-associated source of energy [104]. The implications of this unexpected finding for neurological diseases have yet to be explored but it is relevant to note that intracellular levels of lipids transported by PI4P-dependent processes, such as glucosylceramide, are frequently abnormal in diseases such as Parkinson's and Gaucher's [105].

There are some instances in the literature of mutations in protein PH domains causing neurological and neuromuscular diseases. The best-studied example is the $\mathrm{PI}(4,5) \mathrm{P}_{2}$-binding $\mathrm{PH}$ domain of dynamin 2, a GTPase required for the scission of clathrin-coated pits to form clathrin-coated vesicles during endocytosis and also the release of clathrin-coated transport vesicles during Golgi-toendosomal intracellular trafficking. A point mutation (K562E) in the dynamin $2 \mathrm{PH}$ domain that 
abolishes $\mathrm{PI}(4,5) \mathrm{P}_{2}$ binding is associated with a dominant intermediate form of CMT neuropathy [106]. CMT disease describes a spectrum of progressive peripheral neuropathies with varying degrees of severity that can be caused by mutations in at least 60 genes affecting a number of biochemical pathways [107]. Mutations within the PH domain of this dynamin isoform have also been found in patients affected by other variations of CMT disease and also centronuclear myopathy [108-116]. However, it is important to note that not all disease-causing mutations within the dynamin $\mathrm{PH}$ domain also cause impaired $\mathrm{PI}(4,5) \mathrm{P}_{2}$ binding [114]. Moreover, this type of disease association is not exclusive to dynamin isoforms and there are now several reports demonstrating that mutations in the PH domains of PLEKHG5 can also give rise to CMT symptoms $[117,118]$ and paediatric-onset lower motor neuron disease [119].

\subsection{CNS disorders caused by PI4P and $\mathrm{PI}(4,5) \mathrm{P}_{2}$ imbalances}

There are examples of inherited but rare multisystem diseases caused by loss of function mutations in the PIP 5-phophatases and these have been extensively discussed in recent reviews of this area [120-123]. Of particular note in a neurological context is oculocerebrorenal syndrome of Lowe, sometimes referred to as Lowe's syndrome or OCRL [124]. This is an X-linked recessive disorder and therefore only affects males. In addition to deleterious effects on the eyes and kidneys, OCRL presents clinically with neurological problems including intellectual impairment, developmental delays and behavioural problems. This disease is caused by loss of function mutations in the OCRL gene, which encodes a multidomain PIP 5-phosphatase that dephosporylates $\mathrm{PI}(4,5) \mathrm{P}_{2}$ to produce PI4P [125-131]. OCRL has been localised to endosomes, the Golgi apparatus, the plasma membrane, phagosomes [132] and, importantly in terms of understanding current thinking on the disease mechanism, clathrin-coated vesicles [133]. Loss of OCRL activity leads to the build-up of $\mathrm{PI}(4,5) \mathrm{P}_{2}$ on endosomal membranes and this feature of the disease drives actin accumulation and cytoskeletal abnormalities [134-138]. It is worth noting though that the case for $\mathrm{PI}(4,5) \mathrm{P}_{2}$ accumulation underlying the neuropathological defects in OCRL is not proven. This is because Dent's disease, 
which is also caused by OCRL dysfunction, does not feature CNS involvement $[136,139,140]$. From this point of view, it is useful to consider how the non-catalytic functions of the OCRL protein might contribute toward the disease symptoms. Of particular interest in this regard is the PH domain of OCRL which does not bind PIPs but which instead contains a clathrin-interacting motif, and it is this motif that targets OCRL to late-stage clathrin-coated pits during endocytosis [137, 141]. OCRL1a, a splice variant only expressed in the brain, has a higher affinity for clathrin than the more ubiquitously expressed OCRL1b variant, and thus it may be specifically the loss of this proteininteraction function that causes the neurological defects associated specifically with OCRL as opposed to Dent's disease [142]. Reports that non-catalytic mutations in the APPL1-binding domain of OCRL are pathological [143] further support the idea that the phenotype of Lowe's disease may be an aggregate manifestation of deficiencies in the OCRL1 protein interactome in tandem with abrogated $\mathrm{PI}(4,5) \mathrm{P}_{2}$ homeostasis [144].

When considering the role of OCRL in degrading $\mathrm{PI}(4,5) \mathrm{P}_{2}$, it is important to remember that there are other neuronal PIP phosphatases such as PIPP (INPP5J) and SHIP2, which can catalyse the D5 dephosphorylation of both $\mathrm{PI}(4,5) \mathrm{P}_{2}$ and $\mathrm{PI}(3,4,5) \mathrm{P}_{3}$ but have nevertheless not yet been implicated in any OCRL-like pathology [120]. Furthermore, mutations of the PIP D5 phosphatases synaptojanin proteins (SYNJ1 and SYNJ2), which have roles in decoating clathrin-coated vesicles, do not feature in either Lowe's or Dent's disease. Hence although speculative, and notwithstanding some differences in PIP substrate preferences, these observations suggest very specific and non-overlapping roles for the D5 phosphatases in neuronal physiology and that dysfunction of these enzymatic pathways in neuronal disease cannot be explained simply by abrogated $\mathrm{PI}(4,5) \mathrm{P}_{2}$ degradation. Instead, alterations to the non-catalytic functions of these enzymes, and also perhaps the highly localised changes to the minor endosomal pools of $\mathrm{PI}(4,5) \mathrm{P}_{2}$ in the membrane domains where these proteins are specifically and temporally targeted, may hold the key to understanding how loss of function in PIP degradation leads to particular patterns of neurodegenerative disease. 


\subsection{Defective PI 3-kinase signalling in neurological disease - overgrowth and myelination disorders}

Phosphorylation of $\mathrm{PI}(4,5) \mathrm{P}_{2}$ on the $\mathrm{D} 3$ position by class I PI3K catalytic subunits (PIK3CA, PIK3CB, PIK3CD and PIK3CG) can generate $\mathrm{PI}(3,4,5) \mathrm{P}_{3}$, a molecule with important roles in both pro-survival [145-147] cell migration signaling [148]. Phosphorylation of either PI4P or PI by class II PI3Ks such as PIK3C2A produces respectively $\mathrm{PI}(3,4) \mathrm{P}_{2}$, a $\mathrm{PIP}$ species recently implicated in clathrin-mediated endocytosis [149] and also PI3P, which functions in primary ciliogenesis [150]. Individual PI3K isoforms can have multiple roles in the CNS. As an example of this diversity in neuronal functions, PIK3CG (more commonly referred to as PI3K $\gamma$ ) is required to maintain blood-brain barrier integrity during ischaemic reperfusion [151], has a function in memory and behaviour through NMDA receptor-stimulated long-term potentiation [152] and is a drug target in neuroinflammatory diseases such as multiple sclerosis [153].

In the nervous system, PI3K activity can be stimulated either by receptor tyrosine kinases or GPCRS; examples include insulin receptors activating PIK3CA isoforms or metabotropic glutamate receptors signaling via PI3KCB (reviewed in [154]). These signalling events dynamically control diverse physiological functions in the nervous system including protein synthesis [155, 156], long-term depression [152, 157, 158] and neuronal morphogenesis [159]. In healthy cells, the duration of $\mathrm{PI}(3,4,5) \mathrm{P}_{3}$ signalling is limited due to its rapid dephosphorylation by PIP phosphatases such as PTEN and SHIP2. Moreover, several neurological diseases arise from gain of function and amplified $\mathrm{PI3K} / \mathrm{Akt} / \mathrm{mTOR}$ signalling and this is principally due to deregulated and constitutive activation of $\mathrm{PI} 3 \mathrm{~K}$ isoforms or loss of $\mathrm{PI}(3,4,5) \mathrm{P}_{3}$ phosphatase activity.

These numerous PI3K functions in the CNS depend on the activation and membrane recruitment of protein kinases such as PDK1 and Akt isoforms and a range of effector proteins with $\mathrm{PI}(3,4,5) \mathrm{P}_{3}$ - and $\mathrm{PI}(3,4) \mathrm{P}_{2}$-binding domains such as ARNO [160], which has been implicated in functions such as dendritic development. Significantly, a number of recent publications have revealed a crucial role for 
$\mathrm{PI}(3,4,5) \mathrm{P}_{3}$-dependent processes $[161]$ and the $\mathrm{PI3K} / \mathrm{Akt} / \mathrm{PTEN} / \mathrm{mTOR}$ signalling axis in myelination $[153,162-175]$, which is a key process in maintaining neuronal transmission, survival and recovery from trauma.

\subsection{PI3K and Akt3 link brain overgrowth with epilepsy and autism.}

In terms of neurological disease, one of the most striking developments in this field has been the number of recent reports implicating activating mutations in enzymes such as PIK3CA and Akt3 in a variety of brain overgrowth syndromes such as megalencephaly. These disorders feature increased numbers of both neurons and glial cells [176-182] and recent discoveries in this area are challenging for ideas that PIK3CA activating mutations and/or PTEN deletion are sufficient to drive malignancy to such an extent that certain cancers could be considered 'addicted' to PI3K signalling [183].

Hemimegalencephaly is a rare disorder featuring overgrowth of only one cerebral hemisphere and severe epilepsy. This type of cortical dysplasia is characterised histologically by dysfunctional cellular proliferation, differentiation and mislocalisation of particular neuronal cell types including GABAergic neurons, which are often dysfunctional in epilepsy [184]. Recently, Lee and colleagues [176] discovered that surgically resected diseased tissue from patients suffering from this disease was subject to a number of somatic mutations expected to cause constitutive activation of PI3K signalling to mTOR. As these mutations were only found in diseased brain regions, the authors concluded that this syndrome could be classified as a genetic mosaic disease. The somatic activating mutations identified were in the PIK3CA, AKT3 and MTOR genes. Interestingly, unlike in cancer where the PIK3CA activating mutation H1047R predominates, in hemimegalencephaly the activating E545K mutation is more common. Other mutations include a substitution in the $\mathrm{N}$-terminal $\mathrm{PH}$ domain of AKT3, which is known to result in increased activation of the enzyme [185]. The biochemical consequences of the mTOR C1483Y mutation are not yet known, but the authors found 
that in least some of these cases there was activation of S6 phosphorylation indicating upregulation of Akt-mTOR signalling. Simultaneous with the report of PI3K/AKT involvement in hemimegalencephaly, Rivière and co-workers [180] reported a range of mutations in AKT3, the regulatory PI3K subunit PIK3R2, and again in the PIK3CA protein in a number of related megalencephalies. Several subsequent studies in this area have also found AKT3 gain of function mutations either by gene amplification [182] or the E17K activating point mutation [179], which taken together demonstrate a remarkable and common dependency for activated and brain-specific Akt3 signalling in a whole spectrum of cerebral overgrowth disorders. In terms of understanding how AKT3 drives these proliferative pathologies, there is strong evidence that that it is due to inhibited cyclin D2 turnover leading to cell cycle defects [186]. Of importance in this regard are the converse findings that akt3 homozygous knockout mice have reduced brain size $[187,188]$ and that microcephaly in human disease is associated with haploinsufficiency of the chromosome 1qlocalised AKT3 gene [189].

An alternative means to amplify $\mathrm{PI}(3,4,5) \mathrm{P}_{3}$ signalling and pathological brain growth would be via a loss of function mutation in PTEN, and there are reports of both frameshift and point mutations in PTEN causing extreme megacephaly and severe epilepsy often associated with autism [190]. Other defects in this lipid pathway, caused by mutations in the D4 phosphatase INPP4A, which dephosphorylates $\mathrm{PI}(3,4) \mathrm{P}_{2}$ to $\mathrm{PI} 3 \mathrm{P}$, have been shown to cause NMDA receptor-mediated excitotoxic cell death, epilepsy and microcephaly [191-194]. In addition to revealing a major role for the PI3K signalling pathway in regulating brain development and size, there is now accumulating evidence that defective PTEN functioning and consequently mTOR activation are important in epilepsy and autism [190, 195-204]. Thus, enzymes in this pathway are candidate drug targets for non-surgical treatment of these neurological disorders.

\subsection{Neurological involvement in PTEN germline mutations and benign tumour growth}


Germline loss of function mutations in PTEN give rise to an array of clinical syndromes, all of which feature benign and disorganised tissue overgrowth manifesting as neoplasia (hamartoma). The tissues affected and the severity of the condition can be highly variable even between siblings [205], but when caused by a germline PTEN loss of function mutation this group of diseases, which include Bannayan-Riley-Ruvalcaba syndrome and Cowden syndrome, are collectively referred to as PTEN hamartoma tumour syndromes (PHTS) [206]. As with sporadic or somatic mutations in PTEN, macrocephaly together with a cognitive impairment and developmental delays are common findings in PHTS. More recent work has found that similar to some somatic cerebral overgrowth disorders, there are instances of PIK3CA and AKT mutations in some Cowden syndrome patients, indicating a potential for upregulated $\mathrm{PI}(3,4,5) \mathrm{P}_{3}$-dependent oncogenic transformation within affected tissues [207]. In line with this, there is a much increased risk of developing breast, thyroid, kidney, endometrial and colon cancers with PHTS [206, 208]. Neurological tumours such as neuromas [209] have sometimes been found in PHTS patients but it is not yet known how this relates mechanistically to PTEN gene anomalies.

\subsection{Activated PI3K signalling: overgrowth versus glioma}

The set of recent findings suggesting that PI3K pathway activations can cause brain overgrowth disorders but not necessarily cancer suggests the need for a critical re-evaluation of the proposed link between PTEN and glioma. The evidence for PTEN involvement in malignant brain tumours has accumulated over many years and for many cancers, there is a wealth of evidence from multiple studies indicating that PTEN is a tumour suppressor [210-216]. Furthermore, the genetic evidence for PTEN involvement in glioma is striking, with over $60 \%$ of advanced gliomas $[215,217-220]$ exhibiting genetic rearrangements leading to loss of PTEN function and knockdown studies on cultured cells demonstrating that ablated PTEN expression causes increased astrocyte proliferation and hypertrophy [221-223]. Many of the physiological roles attributed to PTEN concern the processes that arrange and organise the developing nervous system which, in turn, may relate to the 
function of the enzyme in cell motility and adhesion [224-229]. A detailed characterisation of neuronal function in mice in which PTEN expression was ablated in neurons post-natally revealed that the main deficits were in synaptic plasticity and transmission, particularly in long-term potentiation and long-term depression, which manifested phenotypically as memory impairment [230]. Hence, in addition to developmental roles in organising the developing CNS, PTEN has physiological roles in neuronal transmission, indicating that changes to the enzyme's activity or expression can have multiple consequences that extend beyond cell proliferation.

Another point to consider is that unlike in PTEN overgrowth syndromes where there is often a single gene defect in PTEN or AKT, cancers are driven and evolve through several mutations, and for gliomas there is often co-upregulation of EGFR expression, leading to sustained receptor-driven signalling of not only PI3K but also other pro-oncogenic signalling pathways [210, 213, 231-244]. A switch to PTEN-dependent signalling is often a feature of more advanced tumours, possibly due to chromosome 10 loss of heterozygosity or resistance selection due to drug-induced inhibition of other proliferative pathways $[214,233,234,245]$. In this way, upregulation of non-PIP oncogenic signalling networks may work in concert with PTEN deletions to generate a malignant phenotype and this may explain the mixed success so far in clinical trials of molecules that target solely upstream components of the receptor-PI3K signalling axis [246-251]. While PTEN is very well studied in glioma, other enzymes that can amplify PI3K signalling such as constitutively activating PIK3CA mutations $[147,212,252,253]$ also feature in many patients with this disease and indeed other neurological cancers including anaplastic oligodendrogliomas, anaplastic astrocytomas and medulloblastomas $[254,255]$.

\section{0 $\mathrm{PI}(3,5) \mathrm{P}_{2}$ and Charcot-Marie-Tooth neuropathies}

$\mathrm{PI}(3,5) \mathrm{P}_{2}$ is a quantitatively rare PIP that is found on endosomal membranes where it functions in the control of membrane fusion and dynamics [256]. $\mathrm{PI}(3,5) \mathrm{P}_{2}$ is formed via D5 phosphorylation of PI3P 
catalysed by PIKfyve [58] and is then rapidly dephosphorylated back to PI3P by Sac3, a PI(3,5) $\mathrm{P}_{2}$ 5phosphatase encoded by the FIG4 gene $[55,57,257-264]$. Alternatively, $\mathrm{PI}(3,5) \mathrm{P}_{2}$ can potentially be dephosphorylated to PI5P by as many as six of the catalytically active members of the myotubularinrelated 3-phosphatase family i.e. MTM1 (mutated in X-linked recessive centronuclear myopathy) [265], MTMR2, MTMR3, MTMR4, MTMR6, MTMR7 and MTMR8 (reviewed in [266, 267]). Alterations to $\mathrm{PI}(3,5) \mathrm{P}_{2}$ levels in mice via knockout of the PIKfyve activator ArPIKfyve/Vac14 or Sac3/FIG4 phosphatase lead to substantial neurodegeneration, hypomyelination defects and abrogated intracellular trafficking [268-270]. There are now several examples of neurological diseases in humans, including most prominently particular presentations of CMT disease, which are caused by genetic mutations that affect $\mathrm{PI}(3,5) \mathrm{P}_{2}$ homeostasis [271].

In terms of alterations to PIP metabolism, loss of function mutations in enzymes that dephosphorylate $\mathrm{PI}(3,5) \mathrm{P}_{2}$ are prominent in the CMT4 subgroup of the disease, which is characterised by the paediatric onset of progressive axonal degeneration and associated myelin defects. Amongst the $\mathrm{PI}(3,5) \mathrm{P}_{2}$ phosphatases associated with CMT4 are MTMR2 (CMT4B2) and its structurally related but catalytically inactive protein binding partner MTMR13 [172, 267, 272-278]. Mutations in the $\mathrm{PI}(3,5) \mathrm{P}_{2} 5$-phosphatase Sac3/FIG4 that generates $\mathrm{PI} 3 \mathrm{P}$ have also been implicated in CMT disease (CMT4J) [279], as well as other inherited neuropathies such as Yunis-Varón syndrome and amyotrophic lateral sclerosis $[280,281]$, all of which strengthen the case for a crucial physiological role for $\mathrm{PI}(3,5) \mathrm{P}_{2}$ in maintaining normal neuromuscular functions and in particular myelination. Since the low abundance PIPs $\mathrm{PI}(3,5) \mathrm{P}_{2}, \mathrm{PI} \mathrm{P}$ and $\mathrm{PI} \mathrm{P}$ are found mainly on endosomal and lysosomal membranes, these diseases are manifestations of defective PIP trafficking functions on these intracellular organelles that constitute the intracellular degradative trafficking pathway $[256,269]$. This has led to the suggestion that these pathological examples of intracellular $\mathrm{PI}(3,5) \mathrm{P}_{2}$ dyshomeostasis could be considered as a class of endosomal-lysosomal storage disorder [282].

\subsection{Cilliopathies (Joubert's and MORM syndromes) and INPP5E}


INPP5E is a PIP 5-phosphatase that is highly active against $\mathrm{PI}(4,5) \mathrm{P}_{2}, \mathrm{PI}(3,5) \mathrm{P}_{2}$ and $\mathrm{PI}(3,4,5) \mathrm{P}_{3}[122$, 283]. INPP5E localises to primary cilia [284, 285], which are single, microtubule-dependent, long, thin, membranous projections that are immotile and emanate from the centriole [286]. Primary cilia have been noted on many cell types including neurons [286-289] and while their functions are still being elucidated, they have been shown to function as specialised $\mathrm{Ca}^{2+}$ signalling organelles [290, $291]$ and are also an important site for Hedgehog signalling [292, 293]. Primary cilia from radial glia are important for the formation of the cerebral cortex during brain development [294] and processes such as dendritic arborisation [295] and neuronal migration [296]. Ciliary defects feature in a variety of neurodevelopmental disorders [297] and mutations in INPP5E have been implicated in Joubert's and MORM ciliopathies.

Joubert's syndrome is a ciliopathy characterised by abnormal development of the cerebellum and brainstem, which are identifiable as a signature 'molar tooth' structure when imaged [298]. Joubert's ciliopathy has been associated with mutations in at least nine different genes, amongst which are mutations in the PIP phosphatase domain of INPP5E $[299,300]$. Mutations in ARL13B, a small GTPase that forms a molecular complex with INPP5E [284, 294, 296], have also been implicated in Joubert's syndrome, as have mutations in PDE6D, a protein that binds the membranetargeting prenyl groups of INPP5E $[284,301]$. The related ciliopathy MORM is also due to loss of INPP5E function, although in this autosomal recessive disorder the mutation results in a truncated protein that nevertheless retains PIP phosphatase activity [302] but is no longer correctly targeted to the ciliary axoneme. PI3K signalling is required for the development of primary cilia [150] and current evidence suggests that INPP5E functions in the stabilisation of primary cilia as opposed to cilliogenesis [299]. These recent findings reveal a key role for the INPP5E signalling interactome in maintaining ciliar functionality and this is somewhat reminiscent of the situation in OCRL (another PIP-dependent ciliopathy) where mutations affecting molecular interactions in addition to catalytic activity can cause disease. Hence, the loss of INPP5E function and resulting 5-phosphorylated PIP 
homeostasis tend to cause developmental abnormalities that are deleterious for the developing nervous system.

\subsection{The emerging story of PIPs in Alzheimer's disease}

There is now a wealth of evidence implicating PIPs as potential biomarkers and as drug targets in Alzheimer's disease. One of the most high-profile developments in this area has been the discovery that $\mathrm{PI}$ is one of only 10 serum lipids that can accurately predict memory loss in up to $90 \%$ of cases, 2 years before the onset of dementia symptoms [303]. However, it is not clear yet whether raised serum PI reflects any particular change in PIP metabolism and indeed, the authors concluded that alongside the other biomolecules identified in their lipidomic screen, raised serum PI probably reports increased cell membrane breakdown. However, there are a number of observations that make the case for PIP involvement in Alzheimer's disease. These are:

1. The enrichment of PIP-metabolising enzymes such as PTEN [304] and lipids such as $\mathrm{PI}(4,5) \mathrm{P}_{2}$ [305] in neurofibrillary tangles.

2. Alterations to PIP abundance and metabolism in diseased brains [304, 306-315].

3. Alterations to the catalytic activity of PIP-metabolising enzymes such as synaptojanin [316] and PI4K2A [317, 318], by binding of amyloid $\beta(A \beta)$ peptides and conversely, the stimulation of $A \beta$ ? particular acyl chains [319]. These results point to the existence of reciprocal productfeedback loops on endosomal membranes that facilitate the cross-regulation of enzymes involved in PIP synthesis and amyloid processing. To further support this hypothesis, there is published evidence of a close correlation between cellular $\mathrm{PI}(4,5) \mathrm{P}_{2}$ and 42 -residue $\mathrm{A} \beta$ levels [308]. 
4. Genetic polymorphisms or mutations in genes encoding for PIP-utilising or interacting proteins such as PICALM, INPP5D and SYNJ1 predispose to Alzheimer's disease [320-329]. These genes encode for phosphatidylinositol binding clathrin assembly protein (PICALM) [320-323, 330-334], which contains an N-terminal ANTH domain that binds $\mathrm{PI}(4,5) \mathrm{P}_{2}[335$, $336]$ and can simultaneously bind clathrin by means of a clathrin-binding motif; the $\mathrm{PI}(4,5) \mathrm{P}_{2}$ 5-phosphatase synaptojanin 1 [326, 328, 337], which is required for clathrin-mediated endocytosis [338]; and INPP5D, more commonly known as SHIP1 [339], which like PTEN is a PIP 3-phosphatase that preferentially dephosphorylates $\mathrm{PI}(3,4,5) \mathrm{P}_{3}$ to $\mathrm{PI}(4,5) \mathrm{P}_{2}$. Most recent evidence indicates that alterations to PICALM functioning leads to defects in autophagy and, in turn, this leads to the accumulation of tau, a process important for the development of Alzheimer's disease [333]. While in Down's syndrome, trisomy 21 results in increased SYNJ1 gene copy number. This genomic change causes increased expression of synaoptojanin-1 leading to decreased membrane $\mathrm{PI}(4,5) \mathrm{P}_{2}$ levels and consequently endosomal trafficking defects [326]. This PIP defect is associated with concomitant reductions in A $\beta$ trafficking and clearance and, in this way, may contribute to the development of early-onset Alzheimer's disease, which is common in Down's syndrome [328, 340].

5. PI4P production by the endosomally localised PI kinase PI4K2A is stimulated by ginsenoside, a naturally occurring molecule that promotes $A \beta$ clearance in the brain of a murine Alzheimer's model [341]. This effect may relate to cholesterol modulation of PI4K2A activity and its palmitoylation-dependent targeting to raft-like intracellular domains [27, 43-45, 48]. This may be further evidence that upregulating intracellular PIP production could be an effective means of countering abrogated $A \beta$ clearance. 
6. A recent study has found increased neuronal levels of the $\mathrm{PI}(3,4,5) \mathrm{P}_{3}$-activated protein kinase PDK1 both in Alzheimer's and prion disease brains. This results in increased internalisation, through the caveolar route, of tumour necrosis factor- $\alpha$-converting enzyme (TACE) receptor and subsequently reduced TACE-mediated $\alpha$-secretase activity at the cell surface [342]. Consequently, there is decreased proteolysis of both amyloid precursor and prion proteins and this leads to their aberrant accumulation. There is also a report that PDK1 is required for $A \beta$-mediated cell death [343]. These recent publications provide further evidence that PIP regulation of membrane trafficking pathways exert large effects on neuronal A $\beta$ levels. Similarly, the expression VPS34 (PIK3C3), an endosomal PI3K that synthesises PI3P, is reduced in the brains of Alzheimer's patients and this leads to enhanced processing and reduced sorting of amyloid precursor protein through a mechanism involving ubiquitin-mediated trafficking and the PI3P-binding endosomal sorting complexes required for transport (ESCRT) components Hrs and Tsg101 [344]. VPS34 is widely expressed in the brain and its targeted ablation results in pronounced neurodegeneration and synaptic loss [345]. These combined insights suggest that PIP control of amyloid protein processing is an important process to understand as defects in these pathways are likely to cumulatively lead to amyloid plaque formation in the brain.

\subsection{Synaptojanin: a PIP link between Alzheimer's and Parkinson's diseases and epilepsy?}

The involvement of synaptojanin in Alzheimer's is worth further comment since mutations in SYNJ1 have been identified in a rare familial version of Parkinson's disease [346-348] and also in an inherited form of Parkinson's associated with epilepsy [349]. A separate study also reported a synaptojanin mutation in an inherited form of epilepsy, suggesting that SYNJ1 mutations can have heterogeneous effects on neuronal function that are not necessarily limited to classical Alzheimer's and Parkinson's symptoms [350, 351]. However, whilst Alzheimer's may represent a gain of function in synaptojanin due to trisomy 21, the mutations associated with Parkinson's disease and epilepsy 
are loss of function point mutations in the SAC1 catalytic domain that should have the opposite effect on membrane composition and induce $\mathrm{PI}(4,5) \mathrm{P}_{2}$ accumulation. Interestingly, lipidomic analysis of lipid raft composition in both early stage and incidental Parkinson's patients revealed an increase in phosphatidylinositol levels, which is further evidence that PIP metabolism may be altered in this condition $[352,353]$. Hence, it is possible that both Parkinson's and Alzheimer's, although affecting different brain regions and with different symptoms, are to some extent pathological manifestations of reciprocal PIP imbalances within the CNS. Moreover, PI4K2A modulation by cholesterol and ginsenoside point to a possible underappreciated role for PI4P levels in this equation and indicate that an impaired of balance of $\mathrm{PI} 4 \mathrm{P}$ and $\mathrm{PI}(4,5) \mathrm{P}_{2}$ binding partners may contribute towards the development of these neurological pathologies.

It is worth noting that genetic mutations in synaptojanin 2 have not been found to cause Parkinson's or Alzheimer's disease. In terms of primary structure, the 2 synaptojanin isoforms are most divergent in their C-termini, with synaptojanin 2 containing a proline-rich region that is absent in synaptojanin 1 , even though both proteins are thought to function in clathrin-mediated endocytosis. The SYNJ2 gene has gained some interest due to its potential role in maintaining cognitive ability and mental health in old age $[354,355]$, and also because a catalytically inactivating point mutation in this gene in the Mozart mouse strain leads to deafness caused by hair cell loss [356]. Since both synaptojanin proteins have similar PIP substrate specificities it may be the case that, as with the OCRL phosphatases, alterations to the membrane protein interactome in addition to lipid phosphatase activity may be an understudied determinant of how mutations in the D5 phosphatases can give rise to such a heterogeneous range of neurological defects.

It is important to point out that other branches of the PIP signalling pathway are likely to be important in Parkinson's disease. Particularly relevant in this regard is the mitochondrial protein PINK1 (phosphatase and tensin [PTEN] homologue-induced putative kinase 1), which is a downstream phosphorylation substrate of Akt and has been found to be mutated in a particular 
early-onset inherited form of this neurodegenerative disorder [357-360]. In concordance with this, there is evidence that D2 dopamine receptor signalling via PI3K is anti-apoptotic and thus potentially neuroprotective in Parkinson's disease [361].

\subsection{PIPs in stroke, exocitotoxic cell death and cerebral ischaemia}

While PIPs have many roles in inherited neuropathies, overgrowth syndromes and neurodegenerative disorders, there are also demonstrations that these lipids are important for CNS cell survival following the ischaemic trauma caused by a cerebral haemorrhage (stroke). Excitotoxic cell death due to augmented glutamate stimulation of NMDA receptors and $\mathrm{Ca}^{2+}$ dyshomeostasis is a common consequence in this type of brain injury and PIPs, in particular $\mathrm{PI}(3,4,5) \mathrm{P}_{3}$, have been implicated in this neuropathological process [362].

PIP levels, which are contingent on lipid kinase activity, ATP production and thus mitochondrial function, are known to decrease following periods of cerebral ischaemia [363-366]. Furthermore, there are strong indications from murine genetic models that PI4P production is important for the survival of particular cell populations in the CNS $[18,367]$. In a rat model for transient forebrain ischaemia, PI4KA expression was found to be heavily downregulated, specifically in CA1 pyramidal neurons, as was its upstream lipid product $\mathrm{PI}(4,5) \mathrm{P}_{2}[367]$. This change in PIP metabolism correlated with increased neuronal apoptosis and was found to be reversible in cultured cell lines by reexpression of catalytically active PI4KA [367]. These results are consistent with the idea that PI4P synthesis has anti-apoptotic functions in the brain [18]. However, most of the evidence for PIP involvement in cerebral trauma concerns a neuroprotective function for pro-survival PI3K and Akt signalling pathways [151, 368-376]. However, there is one report that PI3K activity has the opposite effect and promotes neuronal oxidative stress through $\mathrm{PI}(3,4,5) \mathrm{P}_{3}$-dependent neuronal $\mathrm{NADPH}$ oxidase activation [369]. Some of the most unexpected findings in this arena have emanated from studies focused on identifying serum biomarkers from stroke patients. In one such study, an 
unbiased proteomic screen found that an increased serum level of the $\mathrm{PI}(3,4,5) \mathrm{P}_{3}$ phosphatase SHIP1 accurately predicted acute ischaemic stroke [377], whilst another found that anti-PI antibodies were prevalent in a group of young stroke patients [378]. These findings are difficult to rationalise based on any known disease mechanism and require validation in a larger patient cohort. Nevertheless, when viewed together with the demonstration that raised serum $\mathrm{PI}$ is an accurate biomarker for Alzheimer's disease [303], there appears to be an emerging trend for PIP pathway molecules, which are not normally secreted at high levels, to be elevated in the serum of patients with severe neurological diseases. However, further work is needed to clarify the mechanisms that underlie these phenomena and also to probe the general applicability of these findings to other CNS disorders.

\subsection{Conclusions}

PIPs are involved in more or less every type of neurological disease, from rare and often devastating genetic diseases to more common neurodegenerative conditions such as Alzheimer's that are becoming more widespread as life expectancy increases (Table 1). There has been substantial progress, particularly in the last 5 years, in understanding how PIP pathways mediate a range of physiological functions in the CNS and how genetic mutations affecting these pathways can lead to neurological diseases. However, with the notable exceptions of glioma, multiple sclerosis and to some extent Alzheimer's disease, there has been less progress in translating this new knowledge into possible new treatments. Some of these problems are simply down to the fact that this information is novel and it will take some time and financial investment in order to generate, for example, small molecule inhibitors that are both isoform specific and blood-brain barrier permeable. Another issue is the complexity of the neurobiology regulated by the PIP lipids and the presence of compensatory and redundant biochemical pathways that could potentially confer resistance to targeted therapies. Even if treatment strategies remain challenging, it is fair to conclude that biomolecules associated with these pathways may be useful biomarkers for predicting, diagnosing 
and classifying neurological conditions and also for discovering molecular connections between diseases that could inform future treatment strategies. 


\section{Legends}

\section{Table 1.}

List of neurological diseases summarising the proteins, enzymes and PIP species involved.

\section{Figure 1.}

Diagram illustrating PIP metabolic pathways in the CNS and the enzymes that have been implicated in neurological diseases. Note that lipid kinases appear in red and phosphatases in blue.

\section{Figure 2.}

The structures of PI, PI4P and PI(4,5) $\mathrm{P}_{2}$. A schematic diagram illustrating the molecular structures of the most abundant brain PIPs. The molecular species shown here are of the 1-stearoyl, 2arachidonoyl varieties which are the common acyl chain additions found in PIPs from the CNS. The hydrophobic acyl chains anchor the PIPs in the membrane while the hydrophilic inositol headgroup. is exposed to the cytosol. Note that the charge differences between the different PIPs arise from single phosphorylation and dephosphorylation events on the inositol head group moiety and that these changes are due to the catalytic activities of phosphoinositide kinase and phosphatase enzymes. Imbalances in the ratio of PI4P:PI(4,5) $\mathrm{P}_{2}$ may be important in both Lowe's \& Dent's syndromes, Alzheimer's \& Parkinson's diseases. Several inherited conditions with neurological involvement including Andersen-Tawil syndrome and a dominant intermediate presentation of Charcot Marie Tooth neuropathy are caused by mutations that abolish protein binding to $\mathrm{PI}(4,5) \mathrm{P}_{2}$. 


\section{References.}

1. Hammond GR, Machner MP and Balla T (2014) A novel probe for phosphatidylinositol 4phosphate reveals multiple pools beyond the Golgi. J Cell Biol 205:113-26. doi: 10.1083/jcb.201312072

2. Balla T (2013) Phosphoinositides: tiny lipids with giant impact on cell regulation. Physiol Rev 93:1019-137. doi: 10.1152/physrev.00028.2012

3. Ueda Y (2014) The role of phosphoinositides in synapse function. Mol Neurobiol 50:821-38. doi: 10.1007/s12035-014-8768-8

4. Caccamo A, Oddo S, Billings LM, Green KN, Martinez-Coria H, Fisher A and LaFerla FM (2006) $\mathrm{M} 1$ receptors play a central role in modulating AD-like pathology in transgenic mice. Neuron 49:67182. doi: 10.1016/j.neuron.2006.01.020

5. Davie BJ, Christopoulos A and Scammells PJ (2013) Development of M1 mAChR allosteric and bitopic ligands: prospective therapeutics for the treatment of cognitive deficits. ACS Chem Neurosci 4:1026-48. doi: 10.1021/cn400086m

6. Hock C, Maddalena A, Heuser I, Naber D, Oertel W, von der Kammer H, Wienrich M, Raschig A, Deng M, Growdon JH and Nitsch RM (2000) Treatment with the selective muscarinic agonist talsaclidine decreases cerebrospinal fluid levels of total amyloid beta-peptide in patients with Alzheimer's disease. Ann N Y Acad Sci 920:285-91.

7. Hock C, Maddalena A, Raschig A, Muller-Spahn F, Eschweiler G, Hager K, Heuser I, Hampel H, Muller-Thomsen T, Oertel W, Wienrich M, Signorell A, Gonzalez-Agosti C and Nitsch RM (2003) Treatment with the selective muscarinic $\mathrm{m} 1$ agonist talsaclidine decreases cerebrospinal fluid levels of $A$ beta 42 in patients with Alzheimer's disease. Amyloid 10:1-6.

8. Chu Sin Chung P and Kieffer BL (2013) Delta opioid receptors in brain function and diseases. Pharmacol Ther 140:112-20. doi: 10.1016/j.pharmthera.2013.06.003

9. Gaveriaux-Ruff C and Kieffer BL (2011) Delta opioid receptor analgesia: recent contributions from pharmacology and molecular approaches. Behav Pharmacol 22:405-14. doi: 10.1097/FBP.0b013e32834a1f2c

10. Shi TJ, Liu SX, Hammarberg H, Watanabe M, Xu ZQ and Hokfelt T (2008) Phospholipase $\mathrm{C}\{$ beta\}3 in mouse and human dorsal root ganglia and spinal cord is a possible target for treatment of neuropathic pain. Proc Natl Acad Sci U S A 105:20004-8. doi: 10.1073/pnas.0810899105

11. Wright BD, Loo L, Street SE, Ma A, Taylor-Blake B, Stashko MA, Jin J, Janzen WP, Frye SV and Zylka MJ (2014) The lipid kinase PIP5K1C regulates pain signaling and sensitization. Neuron 82:83647. doi: 10.1016/j.neuron.2014.04.006

12. Clayton EL, Minogue S and Waugh MG (2013) Phosphatidylinositol 4-kinases and PI4P metabolism in the nervous system: roles in psychiatric and neurological diseases. Mol Neurobiol 47:361-72. doi: 10.1007/s12035-012-8358-6 
13. Clayton EL, Minogue S and Waugh MG (2013) Mammalian phosphatidylinositol 4-kinases as modulators of membrane trafficking and lipid signaling networks. Prog Lipid Res 52:294-304. doi: S0163-7827(13)00023-4 [pii]

10.1016/j.plipres.2013.04.002

14. Szentpetery Z, Varnai P and Balla T (2010) Acute manipulation of Golgi phosphoinositides to assess their importance in cellular trafficking and signaling. Proc Natl Acad Sci U S A 107:8225-30. doi: 1000157107 [pii]

10.1073/pnas.1000157107

15. Dickson EJ, Jensen JB and Hille B (2014) Golgi and plasma membrane pools of PI(4)P contribute to plasma membrane $\mathrm{PI}(4,5) \mathrm{P} 2$ and maintenance of $\mathrm{KCNQ} 2 / 3$ ion channel current. Proc Natl Acad Sci U S A 111:E2281-90. doi: 10.1073/pnas.1407133111

16. Zhou Q, Li J, Yu H, Zhai Y, Gao Z, Liu Y, Pang X, Zhang L, Schulten K, Sun F and Chen C (2014) Molecular insights into the membrane-associated phosphatidylinositol 4-kinase llalpha. Nat Commun 5:3552. doi: 10.1038/ncomms4552

17. Baumlova A, Chalupska D, Rozycki B, Jovic M, Wisniewski E, Klima M, Dubankova A, Kloer DP, Nencka R, Balla T and Boura E (2014) The crystal structure of the phosphatidylinositol 4-kinase Ilalpha. EMBO Rep 15:1085-92. doi: 10.15252/embr.201438841

18. Simons JP, Al-Shawi R, Minogue S, Waugh MG, Wiedemann C, Evangelou S, Loesch A, Sihra TS, King R, Warner TT and Hsuan JJ (2009) Loss of phosphatidylinositol 4-kinase 2alpha activity causes late onset degeneration of spinal cord axons. Proc Natl Acad Sci U S A 106:11535-9. doi: 0903011106 [pii]

10.1073/pnas.0903011106

19. Craige B, Salazar G and Faundez V (2008) Phosphatidylinositol-4-Kinase Type II Alpha Contains an AP-3 Sorting Motif and a Kinase Domain that are both Required for Endosome Traffic. Mol Biol Cell. doi: E07-12-1239 [pii]

10.1091/mbc.E07-12-1239

20. Larimore J, Tornieri K, Ryder PV, Gokhale A, Zlatic SA, Craige B, Lee JD, Talbot K, Pare JF, Smith $Y$ and Faundez $V$ (2011) The schizophrenia susceptibility factor dysbindin and its associated complex sort cargoes from cell bodies to the synapse. Mol Biol Cell 22:4854-67. doi: mbc.E11-070592 [pii]

\subsection{1/mbc.E11-07-0592}

21. Muthusamy N, Faundez V and Bergson C (2012) Calcyon, a mammalian specific NEEP21 family member, interacts with adaptor protein complex 3 (AP-3) and regulates targeting of AP-3 cargoes. J Neurochem 123:60-72. doi: 10.1111/j.1471-4159.2012.07814.x 
22. Salazar G, Craige B, Wainer BH, Guo J, De Camilli P and Faundez V (2005) Phosphatidylinositol-4-kinase type II alpha is a component of adaptor protein-3-derived vesicles. Mol Biol Cell 16:3692-704. doi: E05-01-0020 [pii]

\subsection{1/mbc.E05-01-0020}

23. Salazar G, Zlatic S, Craige B, Peden AA, Pohl J and Faundez V (2009) Hermansky-Pudlak syndrome protein complexes associate with phosphatidylinositol 4-kinase type II alpha in neuronal and non-neuronal cells. J Biol Chem 284:1790-802. doi: M805991200 [pii]

10.1074/jbc.M805991200

24. Jovic M, Kean MJ, Dubankova A, Boura E, Gingras AC, Brill JA and Balla T (2014) Endosomal sorting of VAMP3 is regulated by PI4K2A. J Cell Sci 127:3745-56. doi: 10.1242/jcs.148809

25. Bojjireddy N, Botyanszki J, Hammond G, Creech D, Peterson R, Kemp DC, Snead M, Brown R, Morrison A, Wilson S, Harrison S, Moore C and Balla T (2014) Pharmacological and genetic targeting of the PI4KA enzyme reveals its important role in maintaining plasma membrane phosphatidylinositol 4-phosphate and phosphatidylinositol 4,5-bisphosphate levels. J Biol Chem 289:6120-32. doi: 10.1074/jbc.M113.531426

26. Willars GB, Nahorski SR and Challiss RA (1998) Differential regulation of muscarinic acetylcholine receptor-sensitive polyphosphoinositide pools and consequences for signaling in human neuroblastoma cells. J Biol Chem 273:5037-46.

27. Minogue S, Chu KM, Westover EJ, Covey DF, Hsuan JJ and Waugh MG (2010) Relationship between phosphatidylinositol 4-phosphate synthesis, membrane organization, and lateral diffusion of PI4KIlalpha at the trans-Golgi network. J Lipid Res 51:2314-24. doi: jlr.M005751 [pii]

10.1194/jlr.M005751

28. Waugh MG (2013) Raft-like membranes from the trans-Golgi network and endosomal compartments. Nat Protoc 8:2429-39. doi: nprot.2013.148 [pii]

\subsection{8/nprot.2013.148}

29. Waugh MG, Minogue S, Anderson JS, Balinger A, Blumenkrantz D, Calnan DP, Cramer R and Hsuan JJ (2003) Localization of a highly active pool of type II phosphatidylinositol 4-kinase in a p97/valosin-containing-protein-rich fraction of the endoplasmic reticulum. Biochem J 373:57-63. doi: 10.1042/BJ20030089

BJ20030089 [pii]

30. Balla A, Tuymetova G, Barshishat M, Geiszt M and Balla T (2002) Characterization of type II phosphatidylinositol 4-kinase isoforms reveals association of the enzymes with endosomal vesicular compartments. J Biol Chem 277:20041-50. doi: 10.1074/jbc.M111807200

31. Guo J, Wenk MR, Pellegrini L, Onofri F, Benfenati F and De Camilli P (2003) Phosphatidylinositol 4-kinase type Ilalpha is responsible for the phosphatidylinositol 4-kinase activity 
associated with synaptic vesicles. Proc Natl Acad Sci U S A 100:3995-4000. doi: $10.1073 /$ pnas. 0230488100

0230488100 [pii]

32. Burgess J, Del Bel LM, Ma Cl, Barylko B, Polevoy G, Rollins J, Albanesi JP, Kramer H and Brill JA (2012) Type II phosphatidylinositol 4-kinase regulates trafficking of secretory granule proteins in Drosophila. Development 139:3040-50. doi: 10.1242/dev.077644

33. Mossinger J, Wieffer M, Krause E, Freund C, Gerth F, Krauss M and Haucke V (2012) Phosphatidylinositol 4-kinase Ilalpha function at endosomes is regulated by the ubiquitin ligase Itch. EMBO Rep. doi: embor2012164 [pii]

\subsection{8/embor.2012.164}

34. Ryder PV, Vistein R, Gokhale A, Seaman MN, Puthenveedu MA and Faundez V (2013) The WASH complex, an endosomal Arp2/3 activator, interacts with the Hermansky-Pudlak syndrome complex BLOC-1 and its cargo phosphatidylinositol-4-kinase type Ilalpha. Mol Biol Cell 24:2269-84. doi: 10.1091/mbc.E13-02-0088

35. Larimore J, Zlatic SA, Gokhale A, Tornieri K, Singleton KS, Mullin AP, Tang J, Talbot K and Faundez V (2014) Mutations in the BLOC-1 subunits dysbindin and muted generate divergent and dosage-dependent phenotypes. J Biol Chem 289:14291-300. doi: 10.1074/jbc.M114.553750

36. Mullin AP, Gokhale A, Larimore J and Faundez V (2011) Cell biology of the BLOC-1 complex subunit dysbindin, a schizophrenia susceptibility gene. Mol Neurobiol 44:53-64. doi: 10.1007/s12035-011-8183-3

37. Zlatic SA, Grossniklaus EJ, Ryder PV, Salazar G, Mattheyses AL, Peden AA and Faundez V (2013) Chemical-genetic disruption of clathrin function spares adaptor complex 3-dependent endosome vesicle biogenesis. Mol Biol Cell 24:2378-88. doi: 10.1091/mbc.E12-12-0860

38. Mullin AP, Gokhale A, Moreno-De-Luca A, Sanyal S, Waddington JL and Faundez V (2013) Neurodevelopmental disorders: mechanisms and boundary definitions from genomes, interactomes and proteomes. Transl Psychiatry 3:e329. doi: 10.1038/tp.2013.108

39. Alfonso Pecchio AR, Cardozo Gizzi AM, Renner ML, Molina-Calavita M and Caputto BL (2011) c-Fos activates and physically interacts with specific enzymes of the pathway of synthesis of polyphosphoinositides. Mol Biol Cell 22:4716-25. doi: mbc.E11-03-0259 [pii]

10.1091/mbc.E11-03-0259

40. Caputto BL, Cardozo Gizzi AM and Gil GA (2014) c-Fos: an AP-1 transcription factor with an additional cytoplasmic, non-genomic lipid synthesis activation capacity. Biochim Biophys Acta 1841:1241-6. doi: 10.1016/j.bbalip.2014.05.007

41. Robinson JW, Leshchyns'ka I, Farghaian H, Hughes WE, Sytnyk V, Neely GG and Cole AR (2014) PI4KIlalpha phosphorylation by GSK3 directs vesicular trafficking to lysosomes. Biochem J. doi: 10.1042/BJ20140497 
42. Barylko B, Gerber SH, Binns DD, Grichine N, Khvotchev M, Sudhof TC and Albanesi JP (2001) A novel family of phosphatidylinositol 4-kinases conserved from yeast to humans. J Biol Chem 276:7705-8. doi: 10.1074/jbc.C000861200

C000861200 [pii]

43. Barylko B, Mao YS, Wlodarski P, Jung G, Binns DD, Sun HQ, Yin HL and Albanesi JP (2009) Palmitoylation controls the catalytic activity and subcellular distribution of phosphatidylinositol 4kinase II\{alpha\}. J Biol Chem 284:9994-10003. doi: M900724200 [pii]

10.1074/jbc.M900724200

44. Barylko B, Wlodarski P, Binns DD, Gerber SH, Earnest S, Sudhof TC, Grichine N and Albanesi JP (2002) Analysis of the catalytic domain of phosphatidylinositol 4-kinase type II. J Biol Chem 277:44366-75. doi: 10.1074/jbc.M203241200

M203241200 [pii]

45. Lu D, Sun HQ, Wang H, Barylko B, Fukata Y, Fukata M, Albanesi JP and Yin HL (2012) Phosphatidylinositol 4-kinase Ilalpha is palmitoylated by Golgi-localized palmitoyltransferases in cholesterol-dependent manner. J Biol Chem 287:21856-65. doi: M112.348094 [pii]

10.1074/jbc.M112.348094

46. Waugh MG, Lawson D, Tan SK and Hsuan JJ (1998) Phosphatidylinositol 4-phosphate synthesis in immunoisolated caveolae-like vesicles and low buoyant density non-caveolar membranes. J Biol Chem 273:17115-21.

47. Waugh MG, Minogue S, Blumenkrantz D, Anderson JS and Hsuan JJ (2003) Identification and characterization of differentially active pools of type Ilalpha phosphatidylinositol 4-kinase activity in unstimulated A431 cells. Biochem J 376:497-503. doi: 10.1042/BJ20031212

\section{BJ20031212 [pii]}

48. Waugh MG, Minogue S, Chotai D, Berditchevski F and Hsuan JJ (2006) Lipid and peptide control of phosphatidylinositol 4-kinase Ilalpha activity on Golgi-endosomal rafts. J Biol Chem 281:3757-63. doi: M506527200 [pii]

10.1074/jbc.M506527200

49. Banerji S, Ngo M, Lane CF, Robinson CA, Minogue S and Ridgway ND (2010) Oxysterol binding protein-dependent activation of sphingomyelin synthesis in the golgi apparatus requires phosphatidylinositol 4-kinase Ilalpha. Mol Biol Cell 21:4141-50. doi: E10-05-0424 [pii]

\subsection{1/mbc.E10-05-0424}

50. Liu T and Lee SY (2013) Phosphatidylinositol 4-phosphate 5-kinase alpha negatively regulates nerve growth factor-induced neurite outgrowth in PC12 cells. Exp Mol Med 45:e16. doi: 10.1038/emm.2013.18 
51. Yamazaki M, Yamauchi Y, Goshima Y and Kanaho Y (2013) Phosphatidylinositol 4-phosphate 5-kinase beta regulates growth cone morphology and semaphorin 3A-triggered growth cone collapse in mouse dorsal root ganglion neurons. Neurosci Lett 547:59-64. doi: 10.1016/j.neulet.2013.04.062

52. Volpicelli-Daley LA, Lucast L, Gong LW, Liu L, Sasaki J, Sasaki T, Abrams CS, Kanaho Y and De Camilli P (2010) Phosphatidylinositol-4-phosphate 5-kinases and phosphatidylinositol 4,5bisphosphate synthesis in the brain. J Biol Chem 285:28708-14. doi: M110.132191 [pii]

\subsection{4/jbc.M110.132191}

53. Wenk MR, Pellegrini L, Klenchin VA, Di Paolo G, Chang S, Daniell L, Arioka M, Martin TF and De Camilli P (2001) PIP kinase Igamma is the major PI(4,5)P(2) synthesizing enzyme at the synapse. Neuron 32:79-88. doi: S0896-6273(01)00456-1 [pii]

54. Bulley SJ, Clarke JH, Droubi A, Giudici ML and Irvine RF (2014) Exploring phosphatidylinositol 5-phosphate 4-kinase function. Adv Biol Regul. doi: 10.1016/j.jbior.2014.09.007

55. Shisheva A (2012) PIKfyve and its Lipid products in health and in sickness. Curr Top Microbiol Immunol 362:127-62. doi: 10.1007/978-94-007-5025-8_7

56. Sbrissa D, Ikonomov OC and Shisheva A (1999) PIKfyve, a mammalian ortholog of yeast Fab1p lipid kinase, synthesizes 5-phosphoinositides. Effect of insulin. J Biol Chem 274:21589-97.

57. Sbrissa D, Ikonomov OC, Filios C, Delvecchio K and Shisheva A (2012) Functional dissociation between PIKfyve-synthesized PtdIns5P and PtdIns(3,5)P2 by means of the PIKfyve inhibitor YM201636. Am J Physiol Cell Physiol 303:C436-46. doi: 10.1152/ajpcell.00105.2012

58. Zolov SN, Bridges D, Zhang Y, Lee WW, Riehle E, Verma R, Lenk GM, Converso-Baran K, Weide T, Albin RL, Saltiel AR, Meisler MH, Russell MW and Weisman LS (2012) In vivo, Pikfyve generates $\mathrm{PI}(3,5) \mathrm{P} 2$, which serves as both a signaling lipid and the major precursor for PI5P. Proc Natl Acad Sci U S A 109:17472-7. doi: 10.1073/pnas.1203106109

59. Narkis G, Ofir R, Landau D, Manor E, Volokita M, Hershkowitz R, Elbedour K and Birk OS (2007) Lethal contractural syndrome type 3 (LCCS3) is caused by a mutation in PIP5K1C, which encodes PIPKI gamma of the phophatidylinsitol pathway. Am J Hum Genet 81:530-9. doi: S00029297(07)61349-4 [pii]

$10.1086 / 520771$

60. Bayot A, Reichman S, Lebon S, Csaba Z, Aubry L, Sterkers G, Husson I, Rak M and Rustin P (2013) Cis-silencing of PIP5K1B evidenced in Friedreich's ataxia patient cells results in cytoskeleton anomalies. Hum Mol Genet 22:2894-904. doi: 10.1093/hmg/ddt144

61. Bayot A and Rustin P (2013) Friedreich's ataxia, frataxin, PIP5K1B: echo of a distant fracas. Oxid Med Cell Longev 2013:725635. doi: 10.1155/2013/725635

62. Carvajal JJ, Pook MA, dos Santos M, Doudney K, Hillermann R, Minogue S, Williamson R, Hsuan JJ and Chamberlain S (1996) The Friedreich's ataxia gene encodes a novel phosphatidylinositol-4- phosphate 5-kinase. Nat Genet 14:157-62. doi: 10.1038/ng1096-157 
63. Liu B and Qin F (2005) Functional control of cold- and menthol-sensitive TRPM8 ion channels by phosphatidylinositol 4,5-bisphosphate. J Neurosci 25:1674-81. doi: 10.1523/JNEUROSCI.363204.2005

64. Huang CL, Feng S and Hilgemann DW (1998) Direct activation of inward rectifier potassium channels by PIP2 and its stabilization by Gbetagamma. Nature 391:803-6. doi: 10.1038/35882

65. Karashima Y, Prenen J, Meseguer V, Owsianik G, Voets T and Nilius B (2008) Modulation of the transient receptor potential channel TRPA1 by phosphatidylinositol 4,5-biphosphate manipulators. Pflugers Arch 457:77-89. doi: 10.1007/s00424-008-0493-6

66. Liu B, Zhang C and Qin F (2005) Functional recovery from desensitization of vanilloid receptor TRPV1 requires resynthesis of phosphatidylinositol 4,5-bisphosphate. J Neurosci 25:483543. doi: 10.1523/JNEUROSCI.1296-05.2005

67. Liu B, Liang H, Liu L and Zhang H (2008) Phosphatidylinositol 4,5-bisphosphate hydrolysis mediates histamine-induced KCNO/M current inhibition. Am J Physiol Cell Physiol 295:C81-91. doi: 10.1152/ajpcell.00028.2008

68. Mandal M and Yan Z (2009) Phosphatidylinositol (4,5)-bisphosphate regulation of N-methylD-aspartate receptor channels in cortical neurons. Mol Pharmacol 76:1349-59. doi: 10.1124/mol.109.058701

69. Rohacs T, Lopes CM, Michailidis I and Logothetis DE (2005) PI(4,5)P2 regulates the activation and desensitization of TRPM8 channels through the TRP domain. Nat Neurosci 8:626-34. doi: $10.1038 / \mathrm{nn} 1451$

70. Suh BC and Hille B (2002) Recovery from muscarinic modulation of M current channels requires phosphatidylinositol 4,5-bisphosphate synthesis. Neuron 35:507-20. doi: S0896627302007900 [pii]

71. Suh BC and Hille B (2008) PIP2 is a necessary cofactor for ion channel function: how and why? Annu Rev Biophys 37:175-95. doi: 10.1146/annurev.biophys.37.032807.125859

72. Telezhkin V, Brown DA and Gibb AJ (2012) Distinct subunit contributions to the activation of M-type potassium channels by PI(4,5)P2. J Gen Physiol 140:41-53. doi: 10.1085/jgp.201210796

73. Whorton MR and MacKinnon R (2011) Crystal structure of the mammalian GIRK2 K+ channel and gating regulation by $G$ proteins, PIP2, and sodium. Cell 147:199-208. doi: 10.1016/j.cell.2011.07.046

74. Zhang M, Meng XY, Cui M, Pascal JM, Logothetis DE and Zhang JF (2014) Selective phosphorylation modulates the PIP2 sensitivity of the CaM-SK channel complex. Nat Chem Biol 10:753-9. doi: 10.1038/nchembio.1592

75. Zhang X, Chen X, Jia C, Geng X, Du X and Zhang H (2010) Depolarization increases phosphatidylinositol (PI) 4,5-bisphosphate level and KCNQ currents through PI 4-kinase mechanisms. J Biol Chem 285:9402-9. doi: M109.068205 [pii]

10.1074/jbc.M109.068205 
76. Zhou P, Yu H, Gu M, Nan FJ, Gao Z and Li M (2013) Phosphatidylinositol 4,5-bisphosphate alters pharmacological selectivity for epilepsy-causing KCNQ potassium channels. Proc Natl Acad Sci U S A 110:8726-31. doi: 10.1073/pnas.1302167110

77. Zhang H, He C, Yan X, Mirshahi T and Logothetis DE (1999) Activation of inwardly rectifying $\mathrm{K}+$ channels by distinct Ptdlns(4,5)P2 interactions. Nat Cell Biol 1:183-8. doi: 10.1038/11103

78. Kobrinsky E, Mirshahi T, Zhang H, Jin T and Logothetis DE (2000) Receptor-mediated hydrolysis of plasma membrane messenger PIP2 leads to K+-current desensitization. Nat Cell Biol 2:507-14. doi: 10.1038/35019544

79. Rohacs T, Chen J, Prestwich GD and Logothetis DE (1999) Distinct specificities of inwardly rectifying $\mathrm{K}(+)$ channels for phosphoinositides. J Biol Chem 274:36065-72.

80. Takahashi N, Hamada-Nakahara S, Itoh Y, Takemura K, Shimada A, Ueda Y, Kitamata M, Matsuoka R, Hanawa-Suetsugu K, Senju Y, Mori MX, Kiyonaka S, Kohda D, Kitao A, Mori Y and Suetsugu S (2014) TRPV4 channel activity is modulated by direct interaction of the ankyrin domain to PI(4,5)P2. Nat Commun 5:4994. doi: 10.1038/ncomms5994

81. Hammond GR, Fischer MJ, Anderson KE, Holdich J, Koteci A, Balla T and Irvine RF (2012) PI4P and $\mathrm{PI}(4,5) \mathrm{P} 2$ are essential but independent lipid determinants of membrane identity. Science 337:727-30. doi: 10.1126/science.1222483

82. Wang W, Whorton MR and MacKinnon R (2014) Quantitative analysis of mammalian GIRK2 channel regulation by $\mathrm{G}$ proteins, the signaling lipid PIP2 and $\mathrm{Na}+$ in a reconstituted system. Elife 3:e03671. doi: 10.7554/eLife.03671

83. Whorton MR and MacKinnon R (2013) X-ray structure of the mammalian GIRK2-betagamma G-protein complex. Nature 498:190-7. doi: 10.1038/nature12241

84. Ballester LY, Vanoye CG and George AL, Jr. (2007) Exaggerated Mg2+ inhibition of Kir2.1 as a consequence of reduced PIP2 sensitivity in Andersen syndrome. Channels (Austin) 1:209-17.

85. Davies NP, Imbrici P, Fialho D, Herd C, Bilsland LG, Weber A, Mueller R, Hilton-Jones D, Ealing J, Boothman BR, Giunti P, Parsons LM, Thomas M, Manzur AY, Jurkat-Rott K, Lehmann-Horn F, Chinnery PF, Rose M, Kullmann DM and Hanna MG (2005) Andersen-Tawil syndrome: new potassium channel mutations and possible phenotypic variation. Neurology 65:1083-9. doi: 10.1212/01.wnl.0000178888.03767.74

86. Donaldson MR, Jensen JL, Tristani-Firouzi M, Tawil R, Bendahhou S, Suarez WA, Cobo AM, Poza JJ, Behr E, Wagstaff J, Szepetowski P, Pereira S, Mozaffar T, Escolar DM, Fu YH and Ptacek LJ (2003) PIP2 binding residues of Kir2.1 are common targets of mutations causing Andersen syndrome. Neurology 60:1811-6.

87. Ma D, Tang XD, Rogers TB and Welling PA (2007) An andersen-Tawil syndrome mutation in Kir2.1 (V302M) alters the G-loop cytoplasmic K+ conduction pathway. J Biol Chem 282:5781-9. doi: 10.1074/jbc.M608776200 
88. D'Avanzo N, Lee SJ, Cheng WW and Nichols CG (2013) Energetics and location of phosphoinositide binding in human Kir2.1 channels. J Biol Chem 288:16726-37. doi: 10.1074/jbc.M113.452540

89. Hansen SB, Tao X and Mackinnon R (2011) Structural basis of PIP2 activation of the classical inward rectifier K+ channel Kir2.2. Nature 477:495-8. doi: 10.1038/nature10370

90. Deng HX, Klein CJ, Yan J, Shi Y, Wu Y, Fecto F, Yau HJ, Yang Y, Zhai H, Siddique N, HedleyWhyte ET, Delong R, Martina M, Dyck PJ and Siddique T (2010) Scapuloperoneal spinal muscular atrophy and CMT2C are allelic disorders caused by alterations in TRPV4. Nat Genet 42:165-9. doi: 10.1038/ng.509

91. Everaerts W, Nilius B and Owsianik G (2010) The vanilloid transient receptor potential channel TRPV4: from structure to disease. Prog Biophys Mol Biol 103:2-17. doi: 10.1016/j.pbiomolbio.2009.10.002

92. Garcia-Elias A, Mrkonjic S, Pardo-Pastor C, Inada H, Hellmich UA, Rubio-Moscardo F, Plata C, Gaudet R, Vicente R and Valverde MA (2013) Phosphatidylinositol-4,5-biphosphate-dependent rearrangement of TRPV4 cytosolic tails enables channel activation by physiological stimuli. Proc Natl Acad Sci U S A 110:9553-8. doi: 10.1073/pnas.1220231110

93. Landoure G, Zdebik AA, Martinez TL, Burnett BG, Stanescu HC, Inada H, Shi Y, Taye AA, Kong L, Munns CH, Choo SS, Phelps CB, Paudel R, Houlden H, Ludlow CL, Caterina MJ, Gaudet R, Kleta R, Fischbeck KH and Sumner CJ (2010) Mutations in TRPV4 cause Charcot-Marie-Tooth disease type 2C. Nat Genet 42:170-4. doi: 10.1038/ng.512

94. Lukacs V, Yudin Y, Hammond GR, Sharma E, Fukami K and Rohacs T (2013) Distinctive changes in plasma membrane phosphoinositides underlie differential regulation of TRPV1 in nociceptive neurons. J Neurosci 33:11451-63. doi: 10.1523/JNEUROSCI.5637-12.2013

95. Lindner M, Leitner MG, Halaszovich CR, Hammond GR and Oliver D (2011) Probing the regulation of TASK potassium channels by $\mathrm{PI}, 5 \mathrm{P}(2)$ with switchable phosphoinositide phosphatases. J Physiol 589:3149-62. doi: jphysiol.2011.208983 [pii]

\subsection{3/jphysiol.2011.208983}

96. Hamilton PJ, Belovich AN, Khelashvili G, Saunders C, Erreger K, Javitch JA, Sitte HH, Weinstein H, Matthies HJ and Galli A (2014) PIP2 regulates psychostimulant behaviors through its interaction with a membrane protein. Nat Chem Biol 10:582-9. doi: 10.1038/nchembio.1545

97. Choudhury P, Srivastava S, Li Z, Ko K, Albaqumi M, Narayan K, Coetzee WA, Lemmon MA and Skolnik EY (2006) Specificity of the myotubularin family of phosphatidylinositol-3-phosphatase is determined by the PH/GRAM domain. J Biol Chem 281:31762-9. doi: 10.1074/jbc.M606344200

98. Chen CL, Lin CF, Wan SW, Wei LS, Chen MC, Yeh TM, Liu HS, Anderson R and Lin YS (2013) Anti-dengue virus nonstructural protein 1 antibodies cause NO-mediated endothelial cell apoptosis via ceramide-regulated glycogen synthase kinase-3beta and NF-kappaB activation. J Immunol 191:1744-52. doi: 10.4049/jimmunol.1201976 
99. Dong XP, Cheng X, Mills E, Delling M, Wang F, Kurz T and Xu H (2008) The type IV mucolipidosis-associated protein TRPML1 is an endolysosomal iron release channel. Nature 455:9926. doi: $10.1038 /$ nature07311

100. Dong XP, Shen D, Wang X, Dawson T, Li X, Zhang Q, Cheng X, Zhang Y, Weisman LS, Delling M and $\mathrm{Xu} \mathrm{H}(2010) \mathrm{PI}(3,5) \mathrm{P}(2)$ controls membrane trafficking by direct activation of mucolipin $\mathrm{Ca}(2+)$ release channels in the endolysosome. Nat Commun 1:38. doi: 10.1038/ncomms1037

101. Chen CC, Keller M, Hess M, Schiffmann R, Urban N, Wolfgardt A, Schaefer M, Bracher F, Biel M, Wahl-Schott C and Grimm C (2014) A small molecule restores function to TRPML1 mutant isoforms responsible for mucolipidosis type IV. Nat Commun 5:4681. doi: 10.1038/ncomms5681

102. Jungmichel S, Sylvestersen KB, Choudhary C, Nguyen S, Mann M and Nielsen ML (2014) Specificity and commonality of the phosphoinositide-binding proteome analyzed by quantitative mass spectrometry. Cell Rep 6:578-91. doi: 10.1016/j.celrep.2013.12.038

103. Stahelin RV, Scott JL and Frick CT (2014) Cellular and molecular interactions of phosphoinositides and peripheral proteins. Chem Phys Lipids 182:3-18. doi: 10.1016/j.chemphyslip.2014.02.002

104. Mesmin B, Bigay J, Moser von Filseck J, Lacas-Gervais S, Drin G and Antonny B (2013) A fourstep cycle driven by $\mathrm{PI}(4) \mathrm{P}$ hydrolysis directs sterol/PI(4)P exchange by the ER-Golgi tether OSBP. Cell 155:830-43. doi: 10.1016/j.cell.2013.09.056

105. Shachar T, Lo Bianco C, Recchia A, Wiessner C, Raas-Rothschild A and Futerman AH (2011) Lysosomal storage disorders and Parkinson's disease: Gaucher disease and beyond. Mov Disord 26:1593-604. doi: 10.1002/mds.23774

106. Zuchner S, Noureddine M, Kennerson M, Verhoeven K, Claeys K, De Jonghe P, Merory J, Oliveira SA, Speer MC, Stenger JE, Walizada G, Zhu D, Pericak-Vance MA, Nicholson G, Timmerman V and Vance JM (2005) Mutations in the pleckstrin homology domain of dynamin 2 cause dominant intermediate Charcot-Marie-Tooth disease. Nat Genet 37:289-94. doi: 10.1038/ng1514

107. Rossor AM, Polke JM, Houlden H and Reilly MM (2013) Clinical implications of genetic advances in Charcot-Marie-Tooth disease. Nat Rev Neurol 9:562-71. doi: 10.1038/nrneurol.2013.179 108. Bitoun M, Durieux AC, Prudhon B, Bevilacqua JA, Herledan A, Sakanyan V, Urtizberea A, Cartier L, Romero NB and Guicheney P (2009) Dynamin 2 mutations associated with human diseases impair clathrin-mediated receptor endocytosis. Hum Mutat 30:1419-27. doi: 10.1002/humu.21086

109. Bitoun M, Stojkovic T, Prudhon B, Maurage CA, Latour P, Vermersch P and Guicheney P (2008) A novel mutation in the dynamin 2 gene in a Charcot-Marie-Tooth type 2 patient: clinical and pathological findings. Neuromuscul Disord 18:334-8. doi: 10.1016/j.nmd.2008.01.005

110. Fabrizi GM, Ferrarini M, Cavallaro T, Cabrini I, Cerini R, Bertolasi L and Rizzuto N (2007) Two novel mutations in dynamin-2 cause axonal Charcot-Marie-Tooth disease. Neurology 69:291-5. doi: 10.1212/01.wnl.0000265820.51075.61 
111. Gonzalez-Jamett AM, Momboisse F, Haro-Acuna V, Bevilacqua JA, Caviedes P and Cardenas AM (2013) Dynamin-2 function and dysfunction along the secretory pathway. Front Endocrinol (Lausanne) 4:126. doi: 10.3389/fendo.2013.00126

112. James NG, Digman MA, Ross JA, Barylko B, Wang L, Li J, Chen Y, Mueller JD, Gratton E, Albanesi JP and Jameson DM (2014) A mutation associated with centronuclear myopathy enhances the size and stability of dynamin 2 complexes in cells. Biochim Biophys Acta 1840:315-21. doi: 10.1016/j.bbagen.2013.09.001

113. Jungbluth H, Cullup T, Lillis S, Zhou H, Abbs S, Sewry C and Muntoni F (2010) Centronuclear myopathy with cataracts due to a novel dynamin 2 (DNM2) mutation. Neuromuscul Disord 20:49-52. doi: 10.1016/j.nmd.2009.10.005

114. Kenniston JA and Lemmon MA (2010) Dynamin GTPase regulation is altered by PH domain mutations found in centronuclear myopathy patients. EMBO J 29:3054-67. doi: 10.1038/emboj.2010.187

115. Kierdaszuk B, Berdynski M, Karolczak J, Redowicz MJ, Zekanowski C and Kaminska AM (2013) A novel mutation in the DNM2 gene impairs dynamin 2 localization in skeletal muscle of a patient with late onset centronuclear myopathy. Neuromuscul Disord 23:219-28. doi: 10.1016/j.nmd.2012.12.007

116. Melberg A, Kretz C, Kalimo H, Wallgren-Pettersson C, Toussaint A, Bohm J, Stalberg E and Laporte J (2010) Adult course in dynamin 2 dominant centronuclear myopathy with neonatal onset. Neuromuscul Disord 20:53-6. doi: 10.1016/j.nmd.2009.10.006

117. Azzedine H, Zavadakova P, Plante-Bordeneuve V, Vaz Pato M, Pinto N, Bartesaghi L, Zenker J, Poirot O, Bernard-Marissal N, Arnaud Gouttenoire E, Cartoni R, Title A, Venturini G, Medard JJ, Makowski E, Schols L, Claeys KG, Stendel C, Roos A, Weis J, Dubourg O, Leal Loureiro J, Stevanin G, Said G, Amato A, Baraban J, LeGuern E, Senderek J, Rivolta C and Chrast R (2013) PLEKHG5 deficiency leads to an intermediate form of autosomal-recessive Charcot-Marie-Tooth disease. Hum Mol Genet 22:4224-32. doi: $10.1093 / \mathrm{hmg} / \mathrm{ddt} 274$

118. Kim HJ, Hong YB, Park JM, Choi YR, Kim YJ, Yoon BR, Koo H, Yoo JH, Kim SB, Park M, Chung KW and Choi BO (2013) Mutations in the PLEKHG5 gene is relevant with autosomal recessive intermediate Charcot-Marie-Tooth disease. Orphanet J Rare Dis 8:104. doi: 10.1186/1750-1172-8104

119. Maystadt I, Rezsohazy R, Barkats M, Duque S, Vannuffel P, Remacle S, Lambert B, Najimi M, Sokal E, Munnich A, Viollet $L$ and Verellen-Dumoulin C (2007) The nuclear factor kappaB-activator gene PLEKHG5 is mutated in a form of autosomal recessive lower motor neuron disease with childhood onset. Am J Hum Genet 81:67-76. doi: 10.1086/518900

120. Billcliff PG and Lowe M (2014) Inositol lipid phosphatases in membrane trafficking and human disease. Biochem J 461:159-75. doi: 10.1042/BJ20140361

121. Pirruccello M and De Camilli P (2012) Inositol 5-phosphatases: insights from the Lowe syndrome protein OCRL. Trends Biochem Sci 37:134-43. doi: 10.1016/j.tibs.2012.01.002 
122. Hakim S, Bertucci MC, Conduit SE, Vuong DL and Mitchell CA (2012) Inositol polyphosphate phosphatases in human disease. Curr Top Microbiol Immunol 362:247-314. doi: 10.1007/978-94007-5025-8_12

123. Liu Y and Bankaitis VA (2010) Phosphoinositide phosphatases in cell biology and disease. Prog Lipid Res 49:201-17. doi: 10.1016/j.plipres.2009.12.001

124. Kim HK, Kim JH, Kim YM, Kim GH, Lee BH, Choi JH and Yoo HW (2014) Lowe syndrome: a single center's experience in Korea. Korean J Pediatr 57:140-8. doi: 10.3345/kjp.2014.57.3.140

125. Attree O, Olivos IM, Okabe I, Bailey LC, Nelson DL, Lewis RA, Mclnnes RR and Nussbaum RL (1992) The Lowe's oculocerebrorenal syndrome gene encodes a protein highly homologous to inositol polyphosphate-5-phosphatase. Nature 358:239-42. doi: 10.1038/358239a0

126. Liu T, Yue Z, Wang H, Tong H and Sun L (2014) Novel Mutation of OCRL1 in Lowe Syndrome. Indian J Pediatr. doi: 10.1007/s12098-014-1581-6

127. Pasternack SM, Bockenhauer D, Refke M, Tasic V, Draaken M, Conrad C, Born M, Betz RC, Reutter $\mathrm{H}$ and Ludwig M (2013) A premature termination mutation in a patient with Lowe syndrome without congenital cataracts: dropping the "O" in OCRL. Klin Padiatr 225:29-33. doi: 10.1055/s-00321321900

128. Peces R, Peces C, de Sousa E, Vega C, Selgas R and Nevado J (2013) A novel and de novo deletion in the OCRL1 gene associated with a severe form of Lowe syndrome. Int Urol Nephrol 45:1767-71. doi: 10.1007/s11255-012-0246-5

129. Kanik A, Kasap-Demir B, Atesli R, Eliacik K, Yavascan O and Helvaci M (2013) A novel OCRL1 gene mutation in a Turkish child with Lowe syndrome. Turk J Pediatr 55:82-5.

130. Sugimoto K, Nishi H, Miyazawa T, Fujita S, Okada M and Takemura T (2014) A novel OCRL1 mutation in a patient with the mild phenotype of lowe syndrome. Tohoku J Exp Med 232:163-6.

131. Tresaugues L, Silvander C, Flodin S, Welin M, Nyman T, Graslund S, Hammarstrom M, Berglund $\mathrm{H}$ and Nordlund $\mathrm{P}$ (2014) Structural basis for phosphoinositide substrate recognition, catalysis, and membrane interactions in human inositol polyphosphate 5-phosphatases. Structure 22:744-55. doi: 10.1016/j.str.2014.01.013

132. Bohdanowicz M, Balkin DM, De Camilli P and Grinstein S (2012) Recruitment of OCRL and Inpp5B to phagosomes by Rab5 and APPL1 depletes phosphoinositides and attenuates Akt signaling. Mol Biol Cell 23:176-87. doi: mbc.E11-06-0489 [pii]

10.1091/mbc.E11-06-0489

133. Mehta ZB, Pietka G and Lowe M (2014) The cellular and physiological functions of the Lowe syndrome protein OCRL1. Traffic 15:471-87. doi: 10.1111/tra.12160

134. Dambournet D, Machicoane $M$, Chesneau L, Sachse $M$, Rocancourt M, El Marjou A, Formstecher E, Salomon R, Goud B and Echard A (2011) Rab35 GTPase and OCRL phosphatase remodel lipids and F-actin for successful cytokinesis. Nat Cell Biol 13:981-8. doi: ncb2279 [pii]

$10.1038 /$ ncb2279 
135. Vicinanza M, Di Campli A, Polishchuk E, Santoro M, Di Tullio G, Godi A, Levtchenko E, De Leo MG, Polishchuk R, Sandoval L, Marzolo MP and De Matteis MA (2011) OCRL controls trafficking through early endosomes via Ptdlns4,5P(2)-dependent regulation of endosomal actin. EMBO J 30:4970-85. doi: emboj2011354 [pii]

10.1038/emboj.2011.354

136. Montjean R, Aoidi R, Desbois P, Rucci J, Trichet M, Salomon R, Rendu J, Faure J, Lunardi J, Gacon G, Billuart P and Dorseuil O (2014) OCRL-mutated fibroblasts from patients with Dent-2 disease exhibit INPP5B-independent phenotypic variability relatively to Lowe syndrome cells. Hum Mol Genet. doi: 10.1093/hmg/ddu514

137. Nandez R, Balkin DM, Messa M, Liang L, Paradise S, Czapla H, Hein MY, Duncan JS, Mann M and De Camilli $P$ (2014) A role of OCRL in clathrin-coated pit dynamics and uncoating revealed by studies of Lowe syndrome cells. Elife 3:e02975. doi: 10.7554/eLife.02975

138. Noakes CJ, Lee G and Lowe M (2011) The PH domain proteins IPIP27A and B link OCRL1 to receptor recycling in the endocytic pathway. Mol Biol Cell 22:606-23. doi: 10.1091/mbc.E10-08-0730 139. Coon BG, Mukherjee D, Hanna CB, Riese DJ, 2nd, Lowe M and Aguilar RC (2009) Lowe syndrome patient fibroblasts display Ocrl1-specific cell migration defects that cannot be rescued by the homologous Inpp5b phosphatase. Hum Mol Genet 18:4478-91. doi: 10.1093/hmg/ddp407

140. Devuyst $O$ and Thakker RV (2010) Dent's disease. Orphanet J Rare Dis 5:28. doi: 10.1186/1750-1172-5-28

141. Mao Y, Balkin DM, Zoncu R, Erdmann KS, Tomasini L, Hu F, Jin MM, Hodsdon ME and De Camilli P (2009) A PH domain within OCRL bridges clathrin-mediated membrane trafficking to phosphoinositide metabolism. EMBO J 28:1831-42. doi: emboj2009155 [pii]

10.1038/emboj.2009.155

142. Choudhury R, Noakes CJ, McKenzie E, Kox C and Lowe M (2009) Differential clathrin binding and subcellular localization of OCRL1 splice isoforms. J Biol Chem 284:9965-73. doi: M807442200 [pii]

\subsection{4/jbc.M807442200}

143. McCrea HJ, Paradise S, Tomasini L, Addis M, Melis MA, De Matteis MA and De Camilli P (2008) All known patient mutations in the ASH-RhoGAP domains of OCRL affect targeting and APPL1 binding. Biochem Biophys Res Commun 369:493-9. doi: S0006-291X(08)00302-1 [pii]

10.1016/j.bbrc.2008.02.067

144. Pirruccello M, Swan LE, Folta-Stogniew E and De Camilli P (2011) Recognition of the F\&H motif by the Lowe syndrome protein OCRL. Nat Struct Mol Biol 18:789-95. doi: 10.1038/nsmb.2071

145. Philpott KL, McCarthy MJ, Klippel A and Rubin LL (1997) Activated phosphatidylinositol 3kinase and Akt kinase promote survival of superior cervical neurons. J Cell Biol 139:809-15. 
146. Shien $T$, Doihara H, Hara H, Takahashi H, Yoshitomi S, Taira N, Ishibe $Y$, Teramoto J, Aoe M and Shimizu N (2004) PLC and PI3K pathways are important in the inhibition of EGF-induced cell migration by gefitinib ('Iressa', ZD1839). Breast Cancer 11:367-73.

147. Weber GL, Parat MO, Binder ZA, Gallia GL and Riggins GJ (2011) Abrogation of PIK3CA or PIK3R1 reduces proliferation, migration, and invasion in glioblastoma multiforme cells. Oncotarget 2:833-49.

148. Piccolo E, Innominato PF, Mariggio MA, Maffucci T, lacobelli S and Falasca M (2002) The mechanism involved in the regulation of phospholipase Cgamma1 activity in cell migration. Oncogene 21:6520-9. doi: 10.1038/sj.onc.1205821

1205821 [pii]

149. Posor Y, Eichhorn-Gruenig M, Puchkov D, Schoneberg J, Ullrich A, Lampe A, Muller R, Zarbakhsh S, Gulluni F, Hirsch E, Krauss M, Schultz C, Schmoranzer J, Noe F and Haucke V (2013) Spatiotemporal control of endocytosis by phosphatidylinositol-3,4-bisphosphate. Nature 499:233-7. doi: $10.1038 /$ nature12360

150. Franco I, Gulluni F, Campa CC, Costa C, Margaria JP, Ciraolo E, Martini M, Monteyne D, De Luca E, Germena G, Posor Y, Maffucci T, Marengo S, Haucke V, Falasca M, Perez-Morga D, Boletta A, Merlo GR and Hirsch E (2014) PI3K class II alpha controls spatially restricted endosomal Ptdlns3P and Rab11 activation to promote primary cilium function. Dev Cell 28:647-58. doi: 10.1016/j.devcel.2014.01.022

151. Jin R, Song Z, Yu S, Piazza A, Nanda A, Penninger JM, Granger DN and Li G (2011) Phosphatidylinositol-3-kinase gamma plays a central role in blood-brain barrier dysfunction in acute experimental stroke. Stroke 42:2033-44. doi: 10.1161/STROKEAHA.110.601369

152. Kim JI, Lee HR, Sim SE, Baek J, Yu NK, Choi JH, Ko HG, Lee YS, Park SW, Kwak C, Ahn SJ, Choi SY, Kim H, Kim KH, Backx PH, Bradley CA, Kim E, Jang DJ, Lee K, Kim SJ, Zhuo M, Collingridge GL and Kaang BK (2011) PI3Kgamma is required for NMDA receptor-dependent long-term depression and behavioral flexibility. Nat Neurosci 14:1447-54. doi: 10.1038/nn.2937

153. Li H, Park D, Abdul-Muneer PM, Xu B, Wang H, Xing B, Wu D and Li S (2013) PI3Kgamma inhibition alleviates symptoms and increases axon number in experimental autoimmune encephalomyelitis mice. Neuroscience 253:89-99. doi: 10.1016/j.neuroscience.2013.08.051

154. Gross C and Bassell GJ (2014) Neuron-specific regulation of class I PI3K catalytic subunits and their dysfunction in brain disorders. Front Mol Neurosci 7:12. doi: 10.3389/fnmol.2014.00012

155. Gross C and Bassell GJ (2012) Excess protein synthesis in FXS patient lymphoblastoid cells can be rescued with a p110beta-selective inhibitor. Mol Med 18:336-45. doi: 10.2119/molmed.2011.00363

156. Gross C, Nakamoto M, Yao X, Chan CB, Yim SY, Ye K, Warren ST and Bassell GJ (2010) Excess phosphoinositide 3-kinase subunit synthesis and activity as a novel therapeutic target in fragile $X$ syndrome. J Neurosci 30:10624-38. doi: 10.1523/JNEUROSCI.0402-10.2010 
157. Hou L and Klann E (2004) Activation of the phosphoinositide 3-kinase-Akt-mammalian target of rapamycin signaling pathway is required for metabotropic glutamate receptor-dependent longterm depression. J Neurosci 24:6352-61. doi: 10.1523/JNEUROSCI.0995-04.2004

158. Wang Y, Cheng A and Mattson MP (2006) The PTEN phosphatase is essential for long-term depression of hippocampal synapses. Neuromolecular Med 8:329-36. doi: 10.1385/NMM:8:3:329

159. Yokoyama K, Tezuka T, Kotani M, Nakazawa T, Hoshina N, Shimoda Y, Kakuta S, Sudo K, Watanabe K, Iwakura Y and Yamamoto T (2011) NYAP: a phosphoprotein family that links PI3K to WAVE1 signalling in neurons. EMBO J 30:4739-54. doi: 10.1038/emboj.2011.348

160. Hernandez-Deviez DJ, Casanova JE and Wilson JM (2002) Regulation of dendritic development by the ARF exchange factor ARNO. Nat Neurosci 5:623-4. doi: 10.1038/nn865

161. Snaidero N, Mobius W, Czopka T, Hekking LH, Mathisen C, Verkleij D, Goebbels S, Edgar J, Merkler D, Lyons DA, Nave KA and Simons M (2014) Myelin membrane wrapping of CNS axons by $\mathrm{PI}(3,4,5) \mathrm{P3}-$ dependent polarized growth at the inner tongue. Cell 156:277-90. doi: 10.1016/j.cell.2013.11.044

162. Clark RE, Jr., Miskimins WK and Miskimins R (2002) Phosphatidylinositol-3 kinase p85 enhances expression from the myelin basic protein promoter in oligodendrocytes. J Neurochem 83:565-73.

163. De Paula ML, Cui QL, Hossain S, Antel J and Almazan G (2014) The PTEN inhibitor bisperoxovanadium enhances myelination by amplifying IGF-1 signaling in rat and human oligodendrocyte progenitors. Glia 62:64-77. doi: 10.1002/glia.22584

164. Fraser MM, Bayazitov IT, Zakharenko SS and Baker SJ (2008) Phosphatase and tensin homolog, deleted on chromosome 10 deficiency in brain causes defects in synaptic structure, transmission and plasticity, and myelination abnormalities. Neuroscience 151:476-88. doi: 10.1016/j.neuroscience.2007.10.048

165. Maurel P and Salzer JL (2000) Axonal regulation of Schwann cell proliferation and survival and the initial events of myelination requires PI 3-kinase activity. J Neurosci 20:4635-45.

166. Chan CB, Liu X, Zhao L, Liu G, Lee CW, Feng Y and Ye K (2014) PIKE is essential for oligodendroglia development and CNS myelination. Proc Natl Acad Sci U S A 111:1993-8. doi: 10.1073/pnas.1318185111

167. Fledrich R, Stassart RM, Klink A, Rasch LM, Prukop T, Haag L, Czesnik D, Kungl T, Abdelaal TA, Keric N, Stadelmann C, Bruck W, Nave KA and Sereda MW (2014) Soluble neuregulin-1 modulates disease pathogenesis in rodent models of Charcot-Marie-Tooth disease 1A. Nat Med 20:1055-61. doi: $10.1038 / \mathrm{nm} .3664$

168. Goebbels S, Oltrogge JH, Kemper R, Heilmann I, Bormuth I, Wolfer S, Wichert SP, Mobius W, Liu X, Lappe-Siefke C, Rossner MJ, Groszer M, Suter U, Frahm J, Boretius S and Nave KA (2010) Elevated phosphatidylinositol 3,4,5-trisphosphate in glia triggers cell-autonomous membrane wrapping and myelination. J Neurosci 30:8953-64. doi: 10.1523/JNEUROSCI.0219-10.2010 
169. Goebbels S, Oltrogge JH, Wolfer S, Wieser GL, Nientiedt T, Pieper A, Ruhwedel T, Groszer M, Sereda MW and Nave KA (2012) Genetic disruption of Pten in a novel mouse model of tomaculous neuropathy. EMBO Mol Med 4:486-99. doi: 10.1002/emmm.201200227

170. Lebrun-Julien F, Bachmann L, Norrmen C, Trotzmuller M, Kofeler H, Ruegg MA, Hall MN and Suter $U$ (2014) Balanced mTORC1 activity in oligodendrocytes is required for accurate CNS myelination. J Neurosci 34:8432-48. doi: 10.1523/JNEUROSCI.1105-14.2014

171. Narayanan SP, Flores Al, Wang F and Macklin WB (2009) Akt signals through the mammalian target of rapamycin pathway to regulate CNS myelination. I Neurosci 29:6860-70. doi: 10.1523/JNEUROSCI.0232-09.2009

172. Ng AA, Logan AM, Schmidt EJ and Robinson FL (2013) The CMT4B disease-causing phosphatases Mtmr2 and Mtmr13 localize to the Schwann cell cytoplasm and endomembrane compartments, where they depend upon each other to achieve wild-type levels of protein expression. Hum Mol Genet 22:1493-506. doi: 10.1093/hmg/dds562

173. Norrmen C, Figlia G, Lebrun-Julien F, Pereira JA, Trotzmuller M, Kofeler HC, Rantanen V, Wessig C, van Deijk AL, Smit AB, Verheijen MH, Ruegg MA, Hall MN and Suter U (2014) mTORC1 Controls PNS Myelination along the mTORC1-RXRgamma-SREBP-Lipid Biosynthesis Axis in Schwann Cells. Cell Rep. doi: 10.1016/j.celrep.2014.09.001

174. Norrmen C and Suter U (2013) Akt/mTOR signalling in myelination. Biochem Soc Trans 41:944-50. doi: 10.1042/BST20130046

175. Walker CL and Xu XM (2014) PTEN inhibitor bisperoxovanadium protects oligodendrocytes and myelin and prevents neuronal atrophy in adult rats following cervical hemicontusive spinal cord injury. Neurosci Lett 573:64-8. doi: 10.1016/j.neulet.2014.02.039

176. Lee JH, Huynh M, Silhavy JL, Kim S, Dixon-Salazar T, Heiberg A, Scott E, Bafna V, Hill KJ, Collazo A, Funari V, Russ C, Gabriel SB, Mathern GW and Gleeson JG (2012) De novo somatic mutations in components of the PI3K-AKT3-mTOR pathway cause hemimegalencephaly. Nat Genet 44:941-5. doi: 10.1038/ng.2329

177. Mirzaa G, Conway R, Graham JM and Dobyns WB (1993) PIK3CA-Related Segmental Overgrowth. In: Pagon RA, Adam MP, Ardinger HH, Bird TD, Dolan CR, Fong CT, Smith RJH and Stephens K (eds) GeneReviews(R), Seattle (WA)

178. Mirzaa GM, Riviere JB and Dobyns WB (2013) Megalencephaly syndromes and activating mutations in the PI3K-AKT pathway: MPPH and MCAP. Am J Med Genet C Semin Med Genet 163C:122-30. doi: 10.1002/ajmg.c.31361

179. Poduri A, Evrony GD, Cai X, Elhosary PC, Beroukhim R, Lehtinen MK, Hills LB, Heinzen EL, Hill A, Hill RS, Barry BJ, Bourgeois BF, Riviello JJ, Barkovich AJ, Black PM, Ligon KL and Walsh CA (2012) Somatic activation of AKT3 causes hemispheric developmental brain malformations. Neuron 74:418. doi: 10.1016/j.neuron.2012.03.010

180. Riviere JB, Mirzaa GM, O'Roak BJ, Beddaoui M, Alcantara D, Conway RL, St-Onge J, Schwartzentruber JA, Gripp KW, Nikkel SM, Worthylake T, Sullivan CT, Ward TR, Butler HE, Kramer 
NA, Albrecht B, Armour CM, Armstrong L, Caluseriu O, Cytrynbaum C, Drolet BA, Innes AM, Lauzon JL, Lin AE, Mancini GM, Meschino WS, Reggin JD, Saggar AK, Lerman-Sagie T, Uyanik G, Weksberg R, Zirn B, Beaulieu CL, Finding of Rare Disease Genes Canada C, Majewski J, Bulman DE, O'Driscoll M, Shendure J, Graham JM, Jr., Boycott KM and Dobyns WB (2012) De novo germline and postzygotic mutations in AKT3, PIK3R2 and PIK3CA cause a spectrum of related megalencephaly syndromes. Nat Genet 44:934-40. doi: 10.1038/ng.2331

181. Baek ST, Gibbs EM, Gleeson JG and Mathern GW (2013) Hemimegalencephaly, a paradigm for somatic postzygotic neurodevelopmental disorders. Curr Opin Neurol 26:122-7. doi: 10.1097/WCO.0b013e32835ef373

182. Wang D, Zeesman S, Tarnopolsky MA and Nowaczyk MJ (2013) Duplication of AKT3 as a cause of macrocephaly in duplication 1q43q44. Am J Med Genet A 161A:2016-9. doi: 10.1002/ajmg.a.35999

183. She QB, Chandarlapaty S, Ye Q, Lobo J, Haskell KM, Leander KR, DeFeo-Jones D, Huber HE and Rosen N (2008) Breast tumor cells with PI3K mutation or HER2 amplification are selectively addicted to Akt signaling. PLoS One 3:e3065. doi: 10.1371/journal.pone.0003065

184. Bozzi Y, Casarosa S and Caleo M (2012) Epilepsy as a neurodevelopmental disorder. Front Psychiatry 3:19. doi: 10.3389/fpsyt.2012.00019

185. Carpten JD, Faber AL, Horn C, Donoho GP, Briggs SL, Robbins CM, Hostetter G, Boguslawski S, Moses TY, Savage S, Uhlik M, Lin A, Du J, Qian YW, Zeckner DJ, Tucker-Kellogg G, Touchman J, Patel K, Mousses S, Bittner M, Schevitz R, Lai MH, Blanchard KL and Thomas JE (2007) A transforming mutation in the pleckstrin homology domain of AKT1 in cancer. Nature 448:439-44. doi: nature05933 [pii]

\subsection{8/nature05933}

186. Mirzaa GM, Parry DA, Fry AE, Giamanco KA, Schwartzentruber J, Vanstone M, Logan CV, Roberts N, Johnson CA, Singh S, Kholmanskikh SS, Adams C, Hodge RD, Hevner RF, Bonthron DT, Braun KP, Faivre L, Riviere JB, St-Onge J, Gripp KW, Mancini GM, Pang K, Sweeney E, van Esch H, Verbeek N, Wieczorek D, Steinraths M, Majewski J, Consortium FC, Boycott KM, Pilz DT, Ross ME, Dobyns WB and Sheridan EG (2014) De novo CCND2 mutations leading to stabilization of cyclin D2 cause megalencephaly-polymicrogyria-polydactyly-hydrocephalus syndrome. Nat Genet 46:510-5. doi: 10.1038/ng.2948

187. Easton RM, Cho H, Roovers K, Shineman DW, Mizrahi M, Forman MS, Lee VM, Szabolcs M, de Jong R, Oltersdorf T, Ludwig T, Efstratiadis A and Birnbaum MJ (2005) Role for Akt3/protein kinase Bgamma in attainment of normal brain size. Mol Cell Biol 25:1869-78. doi: 10.1128/MCB.25.5.1869-1878.2005

188. Tschopp O, Yang ZZ, Brodbeck D, Dummler BA, Hemmings-Mieszczak M, Watanabe T, Michaelis T, Frahm J and Hemmings BA (2005) Essential role of protein kinase B gamma (PKB gamma/Akt3) in postnatal brain development but not in glucose homeostasis. Development 132:2943-54. doi: 10.1242/dev.01864 
189. Boland E, Clayton-Smith J, Woo VG, McKee S, Manson FD, Medne L, Zackai E, Swanson EA, Fitzpatrick D, Millen KJ, Sherr EH, Dobyns WB and Black GC (2007) Mapping of deletion and translocation breakpoints in 1q44 implicates the serine/threonine kinase AKT3 in postnatal microcephaly and agenesis of the corpus callosum. Am J Hum Genet 81:292-303. doi: 10.1086/519999

190. Butler MG, Dasouki MJ, Zhou XP, Talebizadeh Z, Brown M, Takahashi TN, Miles JH, Wang CH, Stratton R, Pilarski R and Eng C (2005) Subset of individuals with autism spectrum disorders and extreme macrocephaly associated with germline PTEN tumour suppressor gene mutations. J Med Genet 42:318-21. doi: 10.1136/jmg.2004.024646

191. Nystuen A, Legare ME, Shultz LD and Frankel WN (2001) A null mutation in inositol polyphosphate 4-phosphatase type I causes selective neuronal loss in weeble mutant mice. Neuron 32:203-12.

192. Sasaki J, Kofuji S, Itoh R, Momiyama T, Takayama K, Murakami H, Chida S, Tsuya Y, Takasuga S, Eguchi S, Asanuma K, Horie Y, Miura K, Davies EM, Mitchell C, Yamazaki M, Hirai H, Takenawa T, Suzuki A and Sasaki T (2010) The PtdIns(3,4)P(2) phosphatase INPP4A is a suppressor of excitotoxic neuronal death. Nature 465:497-501. doi: 10.1038/nature09023

193. Sheffer R, Bennett-Back O, Yaacov B, Edvardson S, Gomori M, Werner M, Fahham D, Anteby I, Frumkin A, Meiner $V$ and Elpeleg $O$ (2014) Hindbrain malformation and myoclonic seizures associated with a deleterious mutation in the INPP4A gene. Neurogenetics. doi: 10.1007/s10048014-0428-7

194. Wang L, Luo J, Fang M, Jiang G, Zhang X, Yu W and Wang X (2012) A new trick of INPP4A: decreased expression of INPP4A in patients with temporal lobe epilepsy and pilocarpine-induced rat model. Synapse 66:533-41. doi: 10.1002/syn.21540

195. Galanopoulou AS, Gorter JA and Cepeda C (2012) Finding a better drug for epilepsy: the mTOR pathway as an antiepileptogenic target. Epilepsia 53:1119-30. doi: 10.1111/j.15281167.2012.03506.x

196. Huang X, Zhang H, Yang J, Wu J, McMahon J, Lin Y, Cao Z, Gruenthal M and Huang Y (2010) Pharmacological inhibition of the mammalian target of rapamycin pathway suppresses acquired epilepsy. Neurobiol Dis 40:193-9. doi: 10.1016/j.nbd.2010.05.024

197. Pun RY, Rolle IJ, Lasarge CL, Hosford BE, Rosen JM, Uhl JD, Schmeltzer SN, Faulkner C, Bronson SL, Murphy BL, Richards DA, Holland KD and Danzer SC (2012) Excessive activation of mTOR in postnatally generated granule cells is sufficient to cause epilepsy. Neuron 75:1022-34. doi: 10.1016/j.neuron.2012.08.002

198. Schick V, Majores M, Engels G, Spitoni S, Koch A, Elger CE, Simon M, Knobbe C, Blumcke I and Becker AJ (2006) Activation of Akt independent of PTEN and CTMP tumor-suppressor gene mutations in epilepsy-associated Taylor-type focal cortical dysplasias. Acta Neuropathol 112:715-25. doi: 10.1007/s00401-006-0128-y 
199. Weston MC, Chen H and Swann JW (2014) Loss of mTOR repressors Tsc1 or Pten has divergent effects on excitatory and inhibitory synaptic transmission in single hippocampal neuron cultures. Front Mol Neurosci 7:1. doi: 10.3389/fnmol.2014.00001

200. Buxbaum JD, Cai G, Chaste P, Nygren G, Goldsmith J, Reichert J, Anckarsater H, Rastam M, Smith CJ, Silverman JM, Hollander E, Leboyer M, Gillberg C, Verloes A and Betancur C (2007) Mutation screening of the PTEN gene in patients with autism spectrum disorders and macrocephaly. Am J Med Genet B Neuropsychiatr Genet 144B:484-91. doi: 10.1002/ajmg.b.30493

201. McBride KL, Varga EA, Pastore MT, Prior TW, Manickam K, Atkin JF and Herman GE (2010) Confirmation study of PTEN mutations among individuals with autism or developmental delays/mental retardation and macrocephaly. Autism Res 3:137-41. doi: 10.1002/aur.132

202. Orrico A, Galli L, Buoni S, Orsi A, Vonella G and Sorrentino V (2009) Novel PTEN mutations in neurodevelopmental disorders and macrocephaly. Clin Genet 75:195-8. doi: 10.1111/j.13990004.2008.01074.x

203. Varga EA, Pastore M, Prior T, Herman GE and McBride KL (2009) The prevalence of PTEN mutations in a clinical pediatric cohort with autism spectrum disorders, developmental delay, and macrocephaly. Genet Med 11:111-7. doi: 10.1097/GIM.0b013e31818fd762

204. Chang P, Walker MC and Williams RS (2014) Seizure-induced reduction in PIP3 levels contributes to seizure-activity and is rescued by valproic acid. Neurobiol Dis 62:296-306. doi: 10.1016/j.nbd.2013.10.017

205. Granados A, Eng C and Diaz A (2013) Brothers with germline PTEN mutations and persistent hypoglycemia, macrocephaly, developmental delay, short stature, and coagulopathy. J Pediatr Endocrinol Metab 26:137-41. doi: 10.1515/jpem-2012-0227

206. Pilarski R, Burt R, Kohlman W, Pho L, Shannon KM and Swisher E (2013) Cowden syndrome and the PTEN hamartoma tumor syndrome: systematic review and revised diagnostic criteria. J Natl Cancer Inst 105:1607-16. doi: 10.1093/jnci/djt277

207. Orloff MS, He X, Peterson C, Chen F, Chen JL, Mester JL and Eng C (2013) Germline PIK3CA and AKT1 mutations in Cowden and Cowden-like syndromes. Am J Hum Genet 92:76-80. doi: 10.1016/j.ajhg.2012.10.021

208. Lachlan KL (2013) Cowden syndrome and the PTEN hamartoma tumor syndrome: how to define rare genetic syndromes. J Natl Cancer Inst 105:1595-7. doi: 10.1093/jnci/djt290

209. Schaffer JV, Kamino H, Witkiewicz A, McNiff JM and Orlow SJ (2006) Mucocutaneous neuromas: an underrecognized manifestation of PTEN hamartoma-tumor syndrome. Arch Dermatol 142:625-32. doi: 10.1001/archderm.142.5.625

210. Bleeker FE, Lamba S, Zanon C, Molenaar RJ, Hulsebos TJ, Troost D, van Tilborg AA, Vandertop WP, Leenstra S, van Noorden CJ and Bardelli A (2014) Mutational profiling of kinases in glioblastoma. BMC Cancer 14:718. doi: 10.1186/1471-2407-14-718 
211. Backman SA, Stambolic V, Suzuki A, Haight J, Elia A, Pretorius J, Tsao MS, Shannon P, Bolon $B$, Ivy GO and Mak TW (2001) Deletion of Pten in mouse brain causes seizures, ataxia and defects in soma size resembling Lhermitte-Duclos disease. Nat Genet 29:396-403. doi: 10.1038/ng782

212. McDowell KA, Riggins GJ and Gallia GL (2011) Targeting the AKT pathway in glioblastoma. Curr Pharm Des 17:2411-20.

213. Molina JR, Agarwal NK, Morales FC, Hayashi Y, Aldape KD, Cote G and Georgescu MM (2012) PTEN, NHERF1 and PHLPP form a tumor suppressor network that is disabled in glioblastoma. Oncogene 31:1264-74. doi: 10.1038/onc.2011.324

214. Roversi G, Pfundt R, Moroni RF, Magnani I, van Reijmersdal S, Pollo B, Straatman H, Larizza L and Schoenmakers EF (2006) Identification of novel genomic markers related to progression to glioblastoma through genomic profiling of 25 primary glioma cell lines. Oncogene 25:1571-83. doi: 10.1038/sj.onc.1209177

215. Steck PA, Pershouse MA, Jasser SA, Yung WK, Lin H, Ligon AH, Langford LA, Baumgard ML, Hattier T, Davis T, Frye C, Hu R, Swedlund B, Teng DH and Tavtigian SV (1997) Identification of a candidate tumour suppressor gene, MMAC1, at chromosome 10q23.3 that is mutated in multiple advanced cancers. Nat Genet 15:356-62. doi: 10.1038/ng0497-356

216. Xiao WZ, Han DH, Wang F, Wang YQ, Zhu YH, Wu YF, Liu NT and Sun JY (2014) Relationships between PTEN gene mutations and prognosis in glioma: a meta-analysis. Tumour Biol 35:6687-93. doi: 10.1007/s13277-014-1885-1

217. Guan X, Vengoechea J, Zheng S, Sloan AE, Chen Y, Brat DJ, O'Neill BP, de Groot J, Yust-Katz S, Yung WK, Cohen ML, Aldape KD, Rosenfeld S, Verhaak RG and Barnholtz-Sloan JS (2014) Molecular subtypes of glioblastoma are relevant to lower grade glioma. PLoS One 9:e91216. doi: 10.1371/journal.pone.0091216

218. Ichimura K, Schmidt EE, Miyakawa A, Goike HM and Collins VP (1998) Distinct patterns of deletion on $10 p$ and $10 q$ suggest involvement of multiple tumor suppressor genes in the development of astrocytic gliomas of different malignancy grades. Genes Chromosomes Cancer 22:9-15.

219. Sottoriva A, Spiteri I, Piccirillo SG, Touloumis A, Collins VP, Marioni JC, Curtis C, Watts C and Tavare S (2013) Intratumor heterogeneity in human glioblastoma reflects cancer evolutionary dynamics. Proc Natl Acad Sci U S A 110:4009-14. doi: 10.1073/pnas.1219747110

220. Wang SI, Puc J, Li J, Bruce JN, Cairns P, Sidransky D and Parsons R (1997) Somatic mutations of PTEN in glioblastoma multiforme. Cancer Res 57:4183-6.

221. Adachi J, Ohbayashi K, Suzuki $T$ and Sasaki $T$ (1999) Cell cycle arrest and astrocytic differentiation resulting from PTEN expression in glioma cells. J Neurosurg 91:822-30. doi: 10.3171/jns.1999.91.5.0822

222. Fraser MM, Zhu X, Kwon CH, Uhlmann EJ, Gutmann DH and Baker SJ (2004) Pten loss causes hypertrophy and increased proliferation of astrocytes in vivo. Cancer Res 64:7773-9. doi: 10.1158/0008-5472.CAN-04-2487 
223. Groszer M, Erickson R, Scripture-Adams DD, Lesche R, Trumpp A, Zack JA, Kornblum HI, Liu X and $\mathrm{Wu} \mathrm{H}$ (2001) Negative regulation of neural stem/progenitor cell proliferation by the Pten tumor suppressor gene in vivo. Science 294:2186-9. doi: 10.1126/science.1065518

224. Gregorian C, Nakashima J, Le Belle J, Ohab J, Kim R, Liu A, Smith KB, Groszer M, Garcia AD, Sofroniew MV, Carmichael ST, Kornblum HI, Liu X and Wu H (2009) Pten deletion in adult neural stem/progenitor cells enhances constitutive neurogenesis. J Neurosci 29:1874-86. doi: 10.1523/JNEUROSCI.3095-08.2009

225. Li L, Liu F and Ross AH (2003) PTEN regulation of neural development and CNS stem cells. J Cell Biochem 88:24-8. doi: 10.1002/jcb.10312

226. Marino S, Krimpenfort P, Leung C, van der Korput HA, Trapman J, Camenisch I, Berns A and Brandner S (2002) PTEN is essential for cell migration but not for fate determination and tumourigenesis in the cerebellum. Development 129:3513-22.

227. Sakakibara A and Horwitz AF (2006) Mechanism of polarized protrusion formation on neuronal precursors migrating in the developing chicken cerebellum. J Cell Sci 119:3583-92. doi: $10.1242 / j c s .03080$

228. Yue Q, Groszer M, Gil JS, Berk AJ, Messing A, Wu H and Liu X (2005) PTEN deletion in Bergmann glia leads to premature differentiation and affects laminar organization. Development 132:3281-91. doi: 10.1242/dev.01891

229. Molina JR, Hayashi Y, Stephens C and Georgescu MM (2010) Invasive glioblastoma cells acquire stemness and increased Akt activation. Neoplasia 12:453-63.

230. Sperow M, Berry RB, Bayazitov IT, Zhu G, Baker SJ and Zakharenko SS (2012) Phosphatase and tensin homologue (PTEN) regulates synaptic plasticity independently of its effect on neuronal morphology and migration. J Physiol 590:777-92. doi: 10.1113/jphysiol.2011.220236

231. Appin CL and Brat DJ (2014) Molecular genetics of gliomas. Cancer J 20:66-72. doi: 10.1097/PPO.0000000000000020

232. Brennan C, Momota H, Hambardzumyan D, Ozawa T, Tandon A, Pedraza A and Holland E (2009) Glioblastoma subclasses can be defined by activity among signal transduction pathways and associated genomic alterations. PLoS One 4:e7752. doi: 10.1371/journal.pone.0007752

233. Frattini V, Trifonov V, Chan JM, Castano A, Lia M, Abate F, Keir ST, Ji AX, Zoppoli P, Niola F, Danussi C, Dolgalev I, Porrati P, Pellegatta S, Heguy A, Gupta G, Pisapia DJ, Canoll P, Bruce JN, McLendon RE, Yan H, Aldape K, Finocchiaro G, Mikkelsen T, Prive GG, Bigner DD, Lasorella A, Rabadan R and lavarone A (2013) The integrated landscape of driver genomic alterations in glioblastoma. Nat Genet 45:1141-9. doi: 10.1038/ng.2734

234. Jesionek-Kupnicka D, Szybka M, Potemski P, Kulczycka-Wojdala D, Jaskolski D, Bienkowski M, Skowronski W, Papierz W, Kordek R and Zawlik I (2013) Association of loss of heterozygosity with shorter survival in primary glioblastoma patients. Pol J Pathol 64:268-75. 
235. Kalman B, Szep E, Garzuly F and Post DE (2013) Epidermal growth factor receptor as a therapeutic target in glioblastoma. Neuromolecular Med 15:420-34. doi: 10.1007/s12017-013-8229y

236. Lotsch D, Steiner E, Holzmann K, Spiegl-Kreinecker S, Pirker C, Hlavaty J, Petznek H, Hegedus B, Garay T, Mohr T, Sommergruber W, Grusch M and Berger W (2013) Major vault protein supports glioblastoma survival and migration by upregulating the EGFR/PI3K signalling axis. Oncotarget 4:1904-18.

237. Sintupisut N, Liu PL and Yeang CH (2013) An integrative characterization of recurrent molecular aberrations in glioblastoma genomes. Nucleic Acids Res 41:8803-21. doi: 10.1093/nar/gkt656

238. Zhang J, Antonyak MA, Singh G and Cerione RA (2013) A mechanism for the upregulation of EGF receptor levels in glioblastomas. Cell Rep 3:2008-20. doi: 10.1016/j.celrep.2013.05.021

239. Panner A, Crane CA, Weng C, Feletti A, Parsa AT and Pieper RO (2009) A novel PTENdependent link to ubiquitination controls FLIPS stability and TRAIL sensitivity in glioblastoma multiforme. Cancer Res 69:7911-6. doi: 10.1158/0008-5472.CAN-09-1287

240. Nigro JM, Misra A, Zhang L, Smirnov I, Colman H, Griffin C, Ozburn N, Chen M, Pan E, Koul D, Yung WK, Feuerstein BG and Aldape KD (2005) Integrated array-comparative genomic hybridization and expression array profiles identify clinically relevant molecular subtypes of glioblastoma. Cancer Res 65:1678-86. doi: 10.1158/0008-5472.CAN-04-2921

241. Olar A and Aldape KD (2014) Using the molecular classification of glioblastoma to inform personalized treatment. J Pathol 232:165-77. doi: 10.1002/path.4282

242. Carrasco-Garcia E, Saceda M and Martinez-Lacaci I (2014) Role of receptor tyrosine kinases and their ligands in glioblastoma. Cells 3:199-235. doi: 10.3390/cells3020199

243. Francis JM, Zhang CZ, Maire CL, Jung J, Manzo VE, Adalsteinsson VA, Homer H, Haidar S, Blumenstiel B, Pedamallu CS, Ligon AH, Love JC, Meyerson M and Ligon KL (2014) EGFR variant heterogeneity in glioblastoma resolved through single-nucleus sequencing. Cancer Discov. doi: 10.1158/2159-8290.CD-13-0879

244. Johnson BE, Mazor T, Hong C, Barnes M, Aihara K, McLean CY, Fouse SD, Yamamoto S, Ueda H, Tatsuno K, Asthana S, Jalbert LE, Nelson SJ, Bollen AW, Gustafson WC, Charron E, Weiss WA, Smirnov IV, Song JS, Olshen AB, Cha S, Zhao Y, Moore RA, Mungall AJ, Jones SJ, Hirst M, Marra MA, Saito N, Aburatani H, Mukasa A, Berger MS, Chang SM, Taylor BS and Costello JF (2014) Mutational analysis reveals the origin and therapy-driven evolution of recurrent glioma. Science 343:189-93. doi: 10.1126/science.1239947

245. Lo KC, Bailey D, Burkhardt T, Gardina P, Turpaz Y and Cowell JK (2008) Comprehensive analysis of loss of heterozygosity events in glioblastoma using the 100K SNP mapping arrays and comparison with copy number abnormalities defined by BAC array comparative genomic hybridization. Genes Chromosomes Cancer 47:221-37. doi: 10.1002/gcc.20524 
246. Luchman HA, Stechishin OD, Nguyen SA, Lun XQ, Cairncross JG and Weiss S (2014) Dual mTORC1/2 Blockade Inhibits Glioblastoma Brain Tumor Initiating Cells In Vitro and In Vivo and Synergizes with Temozolomide to Increase Orthotopic Xenograft Survival. Clin Cancer Res. doi: 10.1158/1078-0432.CCR-13-3389

247. Wei B, Wang L, Zhao X, Jin Y, Kong D, Hu G and Sun Z (2014) Co-mutated pathways analysis highlights the coordination mechanism in glioblastoma multiforme. Neoplasma 61:424-32.

248. Razis E, Selviaridis P, Labropoulos S, Norris JL, Zhu MJ, Song DD, Kalebic T, Torrens M, Kalogera-Fountzila A, Karkavelas G, Karanastasi S, Fletcher JA and Fountzilas G (2009) Phase II study of neoadjuvant imatinib in glioblastoma: evaluation of clinical and molecular effects of the treatment. Clin Cancer Res 15:6258-66. doi: 10.1158/1078-0432.CCR-08-1867

249. Vitucci M, Karpinich NO, Bash RE, Werneke AM, Schmid RS, White KK, McNeill RS, Huff B, Wang S, Van Dyke T and Miller CR (2013) Cooperativity between MAPK and PI3K signaling activation is required for glioblastoma pathogenesis. Neuro Oncol 15:1317-29. doi: 10.1093/neuonc/not084

250. Fouladi M, Perentesis JP, Phillips CL, Leary S, Reid JM, McGovern RM, Ingle AM, Ahern CH, Ames MM, Houghton P, Doyle LA, Weigel B and Blaney SM (2014) A phase I trial of MK-2206 in children with refractory malignancies: a Children's Oncology Group study. Pediatr Blood Cancer 61:1246-51. doi: 10.1002/pbc.25023

251. Fenton TR, Nathanson D, Ponte de Albuquerque C, Kuga D, Iwanami A, Dang J, Yang H, Tanaka K, Oba-Shinjo SM, Uno M, Inda MM, Wykosky J, Bachoo RM, James CD, DePinho RA, Vandenberg SR, Zhou H, Marie SK, Mischel PS, Cavenee WK and Furnari FB (2012) Resistance to EGF receptor inhibitors in glioblastoma mediated by phosphorylation of the PTEN tumor suppressor at tyrosine 240. Proc Natl Acad Sci U S A 109:14164-9. doi: 10.1073/pnas.1211962109

252. Holand K, Boller D, Hagel C, Dolski S, Treszl A, Pardo OE, Cwiek P, Salm F, Leni Z, Shepherd PR, Styp-Rekowska B, Djonov V, von Bueren AO, Frei K and Arcaro A (2014) Targeting Class IA PI3K Isoforms Selectively Impairs Cell Growth, Survival, and Migration in Glioblastoma. PLoS One 9:e94132. doi: 10.1371/journal.pone.0094132

PONE-D-13-26083 [pii]

253. Lino MM and Merlo A (2011) PI3Kinase signaling in glioblastoma. J Neurooncol 103:417-27. doi: $10.1007 / \mathrm{s} 11060-010-0442-z$

254. Guerreiro AS, Fattet S, Kulesza DW, Atamer A, Elsing AN, Shalaby T, Jackson SP, Schoenwaelder SM, Grotzer MA, Delattre O and Arcaro A (2011) A sensitized RNA interference screen identifies a novel role for the PI3K p110gamma isoform in medulloblastoma cell proliferation and chemoresistance. Mol Cancer Res 9:925-35. doi: 1541-7786.MCR-10-0200 [pii]

10.1158/1541-7786.MCR-10-0200

255. Broderick DK, Di C, Parrett TJ, Samuels YR, Cummins JM, McLendon RE, Fults DW, Velculescu VE, Bigner DD and Yan H (2004) Mutations of PIK3CA in anaplastic oligodendrogliomas, high-grade astrocytomas, and medulloblastomas. Cancer Res 64:5048-50. doi: 10.1158/0008-5472.CAN-04-1170 
256. McCartney AJ, Zhang Y and Weisman LS (2014) Phosphatidylinositol 3,5-bisphosphate: low abundance, high significance. Bioessays 36:52-64. doi: 10.1002/bies.201300012

257. Ikonomov OC, Sbrissa D, Fenner H and Shisheva A (2009) PIKfyve-ArPIKfyve-Sac3 core complex: contact sites and their consequence for Sac3 phosphatase activity and endocytic membrane homeostasis. J Biol Chem 284:35794-806. doi: 10.1074/jbc.M109.037515

258. Ikonomov OC, Sbrissa D, Fligger J, Delvecchio K and Shisheva A (2010) ArPIKfyve regulates Sac3 protein abundance and turnover: disruption of the mechanism by Sac3141T mutation causing Charcot-Marie-Tooth 4J disorder. J Biol Chem 285:26760-4. doi: 10.1074/jbc.C110.154658

259. Ikonomov OC, Sbrissa D, Foti M, Carpentier JL and Shisheva A (2003) PIKfyve controls fluid phase endocytosis but not recycling/degradation of endocytosed receptors or sorting of procathepsin D by regulating multivesicular body morphogenesis. Mol Biol Cell 14:4581-91. doi: 10.1091/mbc.E03-04-0222

260. Ikonomov OC, Sbrissa D, Mlak K, Deeb R, Fligger J, Soans A, Finley RL, Jr. and Shisheva A (2003) Active PIKfyve associates with and promotes the membrane attachment of the late endosome-to-trans-Golgi network transport factor Rab9 effector p40. J Biol Chem 278:50863-71. doi: 10.1074/jbc.M307260200

261. Ikonomov OC, Sbrissa D and Shisheva A (2006) Localized PtdIns 3,5-P2 synthesis to regulate early endosome dynamics and fusion. Am J Physiol Cell Physiol 291:C393-404. doi: 10.1152/ajpcell.00019.2006

262. Sbrissa D, Ikonomov OC, Fenner H and Shisheva A (2008) ArPIKfyve homomeric and heteromeric interactions scaffold PIKfyve and Sac3 in a complex to promote PIKfyve activity and functionality. J Mol Biol 384:766-79. doi: 10.1016/j.jmb.2008.10.009

263. Sbrissa D, Ikonomov OC, Fu Z, Ijuin T, Gruenberg J, Takenawa T and Shisheva A (2007) Core protein machinery for mammalian phosphatidylinositol 3,5-bisphosphate synthesis and turnover that regulates the progression of endosomal transport. Novel Sac phosphatase joins the ArPIKfyvePIKfyve complex. J Biol Chem 282:23878-91. doi: 10.1074/jbc.M611678200

264. Tsujita K, Itoh T, ljuin T, Yamamoto A, Shisheva A, Laporte J and Takenawa T (2004) Myotubularin regulates the function of the late endosome through the gram domainphosphatidylinositol 3,5-bisphosphate interaction. J Biol Chem 279:13817-24. doi: 10.1074/jbc.M312294200

265. Laporte J, Guiraud-Chaumeil C, Vincent MC, Mandel JL, Tanner SM, Liechti-Gallati S, Wallgren-Pettersson C, Dahl N, Kress W, Bolhuis PA, Fardeau M, Samson F and Bertini E (1997) Mutations in the MTM1 gene implicated in X-linked myotubular myopathy. ENMC International Consortium on Myotubular Myopathy. European Neuro-Muscular Center. Hum Mol Genet 6:150511.

266. Davies EM, Sheffield DA, Tibarewal P, Fedele CG, Mitchell CA and Leslie NR (2012) The PTEN and Myotubularin phosphoinositide 3-phosphatases: linking lipid signalling to human disease. Subcell Biochem 58:281-336. doi: 10.1007/978-94-007-3012-0_8 
267. Amoasii L, Hnia K and Laporte J (2012) Myotubularin phosphoinositide phosphatases in human diseases. Curr Top Microbiol Immunol 362:209-33. doi: 10.1007/978-94-007-5025-8_10

268. Winters JJ, Ferguson CJ, Lenk GM, Giger-Mateeva VI, Shrager P, Meisler MH and Giger RJ (2011) Congenital CNS hypomyelination in the Fig4 null mouse is rescued by neuronal expression of the PI(3,5)P(2) phosphatase Fig4. J Neurosci 31:17736-51. doi: 10.1523/JNEUROSCI.1482-11.2011

269. Lenk GM and Meisler MH (2014) Mouse models of PI(3,5)P2 deficiency with impaired lysosome function. Methods Enzymol 534:245-60. doi: 10.1016/B978-0-12-397926-1.00014-7

270. Ferguson CJ, Lenk GM and Meisler MH (2009) Defective autophagy in neurons and astrocytes from mice deficient in PI(3,5)P2. Hum Mol Genet 18:4868-78. doi: 10.1093/hmg/ddp460

271. Vaccari I, Dina G, Tronchere H, Kaufman E, Chicanne G, Cerri F, Wrabetz L, Payrastre B, Quattrini A, Weisman LS, Meisler MH and Bolino A (2011) Genetic interaction between MTMR2 and FIG4 phospholipid phosphatases involved in Charcot-Marie-Tooth neuropathies. PLoS Genet 7:e1002319. doi: 10.1371/journal.pgen.1002319

272. Berger P, Berger I, Schaffitzel C, Tersar K, Volkmer B and Suter U (2006) Multi-level regulation of myotubularin-related protein-2 phosphatase activity by myotubularin-related protein13/set-binding factor-2. Hum Mol Genet 15:569-79. doi: 10.1093/hmg/ddi473

273. Berger P, Bonneick S, Willi S, Wymann M and Suter U (2002) Loss of phosphatase activity in myotubularin-related protein 2 is associated with Charcot-Marie-Tooth disease type 4B1. Hum Mol Genet 11:1569-79.

274. Berger P, Schaffitzel C, Berger I, Ban N and Suter U (2003) Membrane association of myotubularin-related protein 2 is mediated by a pleckstrin homology-GRAM domain and a coiledcoil dimerization module. Proc Natl Acad Sci U S A 100:12177-82. doi: 10.1073/pnas.2132732100

275. Berger P, Tersar K, Ballmer-Hofer K and Suter U (2011) The CMT4B disease-causing proteins MTMR2 and MTMR13/SBF2 regulate AKT signalling. J Cell Mol Med 15:307-15. doi: 10.1111/j.15824934.2009.00967.x

276. Robinson FL, Niesman IR, Beiswenger KK and Dixon JE (2008) Loss of the inactive myotubularin-related phosphatase Mtmr13 leads to a Charcot-Marie-Tooth 4B2-like peripheral neuropathy in mice. Proc Natl Acad Sci U S A 105:4916-21. doi: 10.1073/pnas.0800742105

277. Robinson FL and Dixon JE (2005) The phosphoinositide-3-phosphatase MTMR2 associates with MTMR13, a membrane-associated pseudophosphatase also mutated in type 4B Charcot-MarieTooth disease. J Biol Chem 280:31699-707. doi: 10.1074/jbc.M505159200

278. Schaletzky J, Dove SK, Short B, Lorenzo O, Clague MJ and Barr FA (2003) Phosphatidylinositol-5-phosphate activation and conserved substrate specificity of the myotubularin phosphatidylinositol 3-phosphatases. Curr Biol 13:504-9.

279. Chow CY, Zhang Y, Dowling JJ, Jin N, Adamska M, Shiga K, Szigeti K, Shy ME, Li J, Zhang X, Lupski JR, Weisman LS and Meisler MH (2007) Mutation of FIG4 causes neurodegeneration in the pale tremor mouse and patients with CMT4J. Nature 448:68-72. doi: 10.1038/nature05876 
280. Chow CY, Landers JE, Bergren SK, Sapp PC, Grant AE, Jones JM, Everett L, Lenk GM, McKenna-Yasek DM, Weisman LS, Figlewicz D, Brown RH and Meisler MH (2009) Deleterious variants of FIG4, a phosphoinositide phosphatase, in patients with ALS. Am J Hum Genet 84:85-8. doi: 10.1016/j.ajhg.2008.12.010

281. Kon T, Mori F, Tanji K, Miki Y, Toyoshima Y, Yoshida M, Sasaki H, Kakita A, Takahashi H and Wakabayashi K (2014) ALS-associated protein FIG4 is localized in Pick and Lewy bodies, and also neuronal nuclear inclusions, in polyglutamine and intranuclear inclusion body diseases. Neuropathology 34:19-26. doi: 10.1111/neup.12056

282. Martyn C and Li J (2013) Fig4 deficiency: a newly emerged lysosomal storage disorder? Prog Neurobiol 101-102:35-45. doi: 10.1016/j.pneurobio.2012.11.001

283. Conduit SE, Dyson JM and Mitchell CA (2012) Inositol polyphosphate 5-phosphatases; new players in the regulation of cilia and ciliopathies. FEBS Lett 586:2846-57. doi: 10.1016/j.febslet.2012.07.037

284. Humbert MC, Weihbrecht K, Searby CC, Li Y, Pope RM, Sheffield VC and Seo S (2012) ARL13B, PDE6D, and CEP164 form a functional network for INPP5E ciliary targeting. Proc Natl Acad Sci U S A 109:19691-6. doi: 10.1073/pnas.1210916109

285. Ishikawa H, Thompson J, Yates JR, 3rd and Marshall WF (2012) Proteomic analysis of mammalian primary cilia. Curr Biol 22:414-9. doi: 10.1016/j.cub.2012.01.031

286. Green JA and Mykytyn K (2014) Neuronal primary cilia: an underappreciated signaling and sensory organelle in the brain. Neuropsychopharmacology 39:244-5. doi: 10.1038/npp.2013.203

287. Mandl L and Megele R (1989) Primary cilia in normal human neocortical neurons. Z Mikrosk Anat Forsch 103:425-30.

288. Guemez-Gamboa A, Coufal NG and Gleeson JG (2014) Primary cilia in the developing and mature brain. Neuron 82:511-21. doi: 10.1016/j.neuron.2014.04.024

289. Louvi A and Grove EA (2011) Cilia in the CNS: the quiet organelle claims center stage. Neuron 69:1046-60. doi: 10.1016/j.neuron.2011.03.002

290. DeCaen PG, Delling M, Vien TN and Clapham DE (2013) Direct recording and molecular identification of the calcium channel of primary cilia. Nature 504:315-8. doi: 10.1038/nature12832

291. Delling M, DeCaen PG, Doerner JF, Febvay S and Clapham DE (2013) Primary cilia are specialized calcium signalling organelles. Nature 504:311-4. doi: 10.1038/nature12833

292. Yoshimura K and Takeda S (2012) Hedgehog signaling regulates myelination in the peripheral nervous system through primary cilia. Differentiation 83:S78-85. doi: 10.1016/j.diff.2011.10.006

293. Han YG, Spassky N, Romaguera-Ros M, Garcia-Verdugo JM, Aguilar A, Schneider-Maunoury S and Alvarez-Buylla A (2008) Hedgehog signaling and primary cilia are required for the formation of adult neural stem cells. Nat Neurosci 11:277-84. doi: 10.1038/nn2059

294. Higginbotham H, Guo J, Yokota Y, Umberger NL, Su CY, Li J, Verma N, Hirt J, Ghukasyan V, Caspary T and Anton ES (2013) Arl13b-regulated cilia activities are essential for polarized radial glial scaffold formation. Nat Neurosci 16:1000-7. doi: 10.1038/nn.3451 
295. Guadiana SM, Semple-Rowland S, Daroszewski D, Madorsky I, Breunig JJ, Mykytyn K and Sarkisian MR (2013) Arborization of dendrites by developing neocortical neurons is dependent on primary cilia and type 3 adenylyl cyclase. J Neurosci 33:2626-38. doi: 10.1523/JNEUROSCI.290612.2013

296. Higginbotham H, Eom TY, Mariani LE, Bachleda A, Hirt J, Gukassyan V, Cusack CL, Lai C, Caspary T and Anton ES (2012) Arl13b in primary cilia regulates the migration and placement of interneurons in the developing cerebral cortex. Dev Cell 23:925-38. doi: 10.1016/j.devcel.2012.09.019

297. Valente EM, Rosti RO, Gibbs E and Gleeson JG (2014) Primary cilia in neurodevelopmental disorders. Nat Rev Neurol 10:27-36. doi: 10.1038/nrneurol.2013.247

298. Juric-Sekhar G, Adkins J, Doherty D and Hevner RF (2012) Joubert syndrome: brain and spinal cord malformations in genotyped cases and implications for neurodevelopmental functions of primary cilia. Acta Neuropathol 123:695-709. doi: 10.1007/s00401-012-0951-2

299. Bielas SL, Silhavy JL, Brancati F, Kisseleva MV, Al-Gazali L, Sztriha L, Bayoumi RA, Zaki MS, Abdel-Aleem A, Rosti RO, Kayserili H, Swistun D, Scott LC, Bertini E, Boltshauser E, Fazzi E, Travaglini L, Field SJ, Gayral S, Jacoby M, Schurmans S, Dallapiccola B, Majerus PW, Valente EM and Gleeson JG (2009) Mutations in INPP5E, encoding inositol polyphosphate-5-phosphatase E, link phosphatidyl inositol signaling to the ciliopathies. Nat Genet 41:1032-6. doi: 10.1038/ng.423

300. Travaglini L, Brancati F, Silhavy J, lannicelli M, Nickerson E, Elkhartoufi N, Scott E, Spencer E, Gabriel S, Thomas S, Ben-Zeev B, Bertini E, Boltshauser E, Chaouch M, Cilio MR, de Jong MM, Kayserili H, Ogur G, Poretti A, Signorini S, Uziel G, Zaki MS, International JSG, Johnson C, Attie-Bitach T, Gleeson JG and Valente EM (2013) Phenotypic spectrum and prevalence of INPP5E mutations in Joubert syndrome and related disorders. Eur J Hum Genet 21:1074-8. doi: 10.1038/ejhg.2012.305

301. Thomas S, Wright KJ, Le Corre S, Micalizzi A, Romani M, Abhyankar A, Saada J, Perrault I, Amiel J, Litzler J, Filhol E, Elkhartoufi N, Kwong M, Casanova JL, Boddaert N, Baehr W, Lyonnet S, Munnich A, Burglen L, Chassaing N, Encha-Ravazi F, Vekemans M, Gleeson JG, Valente EM, Jackson PK, Drummond IA, Saunier S and Attie-Bitach T (2014) A homozygous PDE6D mutation in Joubert syndrome impairs targeting of farnesylated INPP5E protein to the primary cilium. Hum Mutat 35:137-46. doi: 10.1002/humu.22470

302. Jacoby M, Cox JJ, Gayral S, Hampshire DJ, Ayub M, Blockmans M, Pernot E, Kisseleva MV, Compere P, Schiffmann SN, Gergely F, Riley JH, Perez-Morga D, Woods CG and Schurmans S (2009) INPP5E mutations cause primary cilium signaling defects, ciliary instability and ciliopathies in human and mouse. Nat Genet 41:1027-31. doi: 10.1038/ng.427

303. Mapstone M, Cheema AK and Fiandaca MS (2014) Plasma phospholipids identify antecedent memory impairment in older adults. 20:415-8. doi: 10.1038/nm.3466

304. Sonoda Y, Mukai H, Matsuo K, Takahashi M, Ono Y, Maeda K, Akiyama H and Kawamata T (2010) Accumulation of tumor-suppressor PTEN in Alzheimer neurofibrillary tangles. Neurosci Lett 471:20-4. doi: 10.1016/j.neulet.2009.12.078 
305. Nishikawa T, Takahashi T, Nakamori M, Yamazaki Y, Kurashige T, Nagano Y, Nishida Y, Izumi Y and Matsumoto M (2014) Phosphatidylinositol-4,5-bisphosphate is enriched in granulovacuolar degeneration bodies and neurofibrillary tangles. Neuropathol Appl Neurobiol 40:489-501. doi: 10.1111/nan.12056

306. Jolles J, Bothmer J, Markerink M and Ravid R (1992) Phosphatidylinositol kinase is reduced in Alzheimer's disease. J Neurochem 58:2326-9.

307. Jolles J, Bothmer J, Markerink M and Ravid R (1993) Reduced phosphatidylinositol kinase activity in Alzheimer's disease: effects of age and onset. Dementia 4:81-6.

308. Landman N, Jeong SY, Shin SY, Voronov SV, Serban G, Kang MS, Park MK, Di Paolo G, Chung S and Kim TW (2006) Presenilin mutations linked to familial Alzheimer's disease cause an imbalance in phosphatidylinositol 4,5-bisphosphate metabolism. Proc Natl Acad Sci U S A 103:19524-9. doi: 10.1073/pnas.0604954103

309. Bothmer J, Markerink M and Jolles J (1994) Phosphoinositide kinase activities in synaptosomes prepared from brains of patients with Alzheimer's disease and controls. Neurosci Lett 176:169-72.

310. Rickle A, Bogdanovic N, Volkmann I, Zhou X, Pei JJ, Winblad B and Cowburn RF (2006) PTEN levels in Alzheimer's disease medial temporal cortex. Neurochem Int 48:114-23. doi: 10.1016/j.neuint.2005.08.014

311. Zhang X, Li F, Bulloj A, Zhang YW, Tong G, Zhang Z, Liao FF and Xu H (2006) Tumorsuppressor PTEN affects tau phosphorylation, aggregation, and binding to microtubules. FASEB J 20:1272-4. doi: 10.1096/fj.06-5721fje

312. Ferrari-DiLeo $G$ and Flynn DD (1993) Diminished muscarinic receptor-stimulated [3H]-PIP2 hydrolysis in Alzheimer's disease. Life Sci 53:PL439-44.

313. Stokes CE and Hawthorne JN (1987) Reduced phosphoinositide concentrations in anterior temporal cortex of Alzheimer-diseased brains. J Neurochem 48:1018-21.

314. Zubenko GS, Stiffler JS, Hughes HB and Martinez AJ (1999) Reductions in brain phosphatidylinositol kinase activities in Alzheimer's disease. Biol Psychiatry 45:731-6. doi: S0006322398000730 [pii]

315. Bennett SA, Valenzuela N, Xu H, Franko B, Fai S and Figeys D (2013) Using neurolipidomics to identify phospholipid mediators of synaptic (dys)function in Alzheimer's Disease. Front Physiol 4:168. doi: 10.3389/fphys.2013.00168

316. Berman DE, Dall'Armi C, Voronov SV, Mclntire LB, Zhang H, Moore AZ, Staniszewski A, Arancio O, Kim TW and Di Paolo G (2008) Oligomeric amyloid-beta peptide disrupts phosphatidylinositol-4,5-bisphosphate metabolism. Nat Neurosci 11:547-54. doi: nn.2100 [pii]

$10.1038 / \mathrm{nn} .2100$

317. Wu B, Kitagawa K, Liu B, Zhang NY, Xiong ZM and Inagaki C (2006) Attenuation of amyloid beta (Abeta)-induced inhibition of phosphatidylinositol 4-kinase activity by Abeta fragments, Abeta20-29 and Abeta31-35. Neurosci Lett 396:148-52. doi: S0304-3940(05)01310-8 [pii] 
10.1016/j.neulet.2005.11.026

318. Xiong ZM, Kitagawa K, Nishiuchi Y, Kimura T and Inagaki C (2007) Protective effects of Abetaderived tripeptide, Abeta(32-34), on Abeta(1-42)-induced phosphatidylinositol 4-kinase inhibition and neurotoxicity. Neurosci Lett 419:247-52. doi: S0304-3940(07)00442-9 [pii]

10.1016/j.neulet.2007.04.022

319. Holmes O, Paturi S, Ye W, Wolfe MS and Selkoe DJ (2012) Effects of membrane lipids on the activity and processivity of purified gamma-secretase. Biochemistry 51:3565-75. doi: $10.1021 /$ bi300303g

320. Karch CM and Goate AM (2014) Alzheimer's Disease Risk Genes and Mechanisms of Disease Pathogenesis. Biol Psychiatry. doi: 10.1016/j.biopsych.2014.05.006

321. Harold D, Abraham R, Hollingworth P, Sims R, Gerrish A, Hamshere ML, Pahwa JS, Moskvina V, Dowzell K, Williams A, Jones N, Thomas C, Stretton A, Morgan AR, Lovestone S, Powell J, Proitsi P, Lupton MK, Brayne C, Rubinsztein DC, Gill M, Lawlor B, Lynch A, Morgan K, Brown KS, Passmore PA, Craig D, McGuinness B, Todd S, Holmes C, Mann D, Smith AD, Love S, Kehoe PG, Hardy J, Mead S, Fox $\mathrm{N}$, Rossor M, Collinge J, Maier W, Jessen F, Schurmann B, van den Bussche H, Heuser I, Kornhuber J, Wiltfang J, Dichgans M, Frolich L, Hampel H, Hull M, Rujescu D, Goate AM, Kauwe JS, Cruchaga C, Nowotny P, Morris JC, Mayo K, Sleegers K, Bettens K, Engelborghs S, De Deyn PP, Van Broeckhoven C, Livingston G, Bass NJ, Gurling H, McQuillin A, Gwilliam R, Deloukas P, Al-Chalabi A, Shaw CE, Tsolaki M, Singleton AB, Guerreiro R, Muhleisen TW, Nothen MM, Moebus S, Jockel KH, Klopp N, Wichmann HE, Carrasquillo MM, Pankratz VS, Younkin SG, Holmans PA, O'Donovan M, Owen MJ and Williams J (2009) Genome-wide association study identifies variants at CLU and PICALM associated with Alzheimer's disease. Nat Genet 41:1088-93. doi: ng.440 [pii]

10.1038/ng.440

322. Schjeide BM, Schnack C, Lambert JC, Lill CM, Kirchheiner J, Tumani H, Otto M, Tanzi RE, Lehrach H, Amouyel P, von Arnim CA and Bertram L (2011) The role of clusterin, complement receptor 1, and phosphatidylinositol binding clathrin assembly protein in Alzheimer disease risk and cerebrospinal fluid biomarker levels. Arch Gen Psychiatry 68:207-13. doi: 68/2/207 [pii]

10.1001/archgenpsychiatry.2010.196

323. Xiao Q, Gil SC, Yan P, Wang Y, Han S, Gonzales E, Perez R, Cirrito JR and Lee JM (2012) Role of Phosphatidylinositol Clathrin Assembly Lymphoid-Myeloid Leukemia (PICALM) in Intracellular Amyloid Precursor Protein (APP) Processing and Amyloid Plaque Pathogenesis. I Biol Chem 287:21279-89. doi: M111.338376 [pii]

10.1074/jbc.M111.338376

324. Ru Y, Yin L, Sun H, Yin S, Pan Q, Wei H, Wu L and Liu S (2012) A micropreparation of mitochondria from cells using magnetic beads with immunoaffinity. Anal Biochem 421:219-26. doi: S0003-2697(11)00747-0 [pii] 
10.1016/j.ab.2011.11.015

325. Arai $Y$, ljuin T, Takenawa T, Becker LE and Takashima S (2002) Excessive expression of synaptojanin in brains with Down syndrome. Brain Dev 24:67-72. doi: S0387760401004053 [pii]

326. Cossec JC, Lavaur J, Berman DE, Rivals I, Hoischen A, Stora S, Ripoll C, Mircher C, Grattau Y, Olivomarin JC, de Chaumont F, Lecourtois M, Antonarakis SE, Veltman JA, Delabar JM, Duyckaerts C, Di Paolo G and Potier MC (2012) Trisomy for Synaptojanin1 in Down syndrome is functionally linked to the enlargement of early endosomes. Hum Mol Genet. doi: dds142 [pii]

\section{$10.1093 / \mathrm{hmg} / \mathrm{dds} 142$}

327. Voronov SV, Frere SG, Giovedi S, Pollina EA, Borel C, Zhang H, Schmidt C, Akeson EC, Wenk MR, Cimasoni L, Arancio O, Davisson MT, Antonarakis SE, Gardiner K, De Camilli P and Di Paolo G (2008) Synaptojanin 1-linked phosphoinositide dyshomeostasis and cognitive deficits in mouse models of Down's syndrome. Proc Natl Acad Sci U S A 105:9415-20. doi: 10.1073/pnas.0803756105

0803756105 [pii]

328. Zhu L, Zhong M, Zhao J, Rhee H, Caesar I, Knight EM, Volpicelli-Daley L, Bustos V, Netzer W, Liu L, Lucast L, Ehrlich ME, Robakis NK, Gandy SE and Cai D (2013) Reduction of synaptojanin 1 accelerates Abeta clearance and attenuates cognitive deterioration in an Alzheimer mouse model. J Biol Chem 288:32050-63. doi: 10.1074/jbc.M113.504365

329. Ruiz A, Heilmann S, Becker T, Hernandez I, Wagner H, Thelen M, Mauleon A, Rosende-Roca M, Bellenguez C, Bis JC, Harold D, Gerrish A, Sims R, Sotolongo-Grau O, Espinosa A, Alegret M, Arrieta JL, Lacour A, Leber M, Becker J, Lafuente A, Ruiz S, Vargas L, Rodriguez O, Ortega G, Dominguez MA, Igap, Mayeux R, Haines JL, Pericak-Vance MA, Farrer LA, Schellenberg GD, Chouraki V, Launer L, van Duijn C, Seshadri S, Antunez C, Breteler MM, Serrano-Rios M, Jessen F, Tarraga L, Nothen MM, Maier W, Boada M and Ramirez A (2014) Follow-up of loci from the International Genomics of Alzheimer's Disease Project identifies TRIP4 as a novel susceptibility gene. Transl Psychiatry 4:e358. doi: 10.1038/tp.2014.2

330. Ando K, Brion JP, Stygelbout V, Suain V, Authelet M, Dedecker R, Chanut A, Lacor P, Lavaur J, Sazdovitch V, Rogaeva E, Potier MC and Duyckaerts C (2013) Clathrin adaptor CALM/PICALM is associated with neurofibrillary tangles and is cleaved in Alzheimer's brains. Acta Neuropathol 125:861-78. doi: 10.1007/s00401-013-1111-z

331. Kanatsu K, Morohashi Y, Suzuki M, Kuroda H, Watanabe T, Tomita T and Iwatsubo T (2014) Decreased CALM expression reduces Abeta42 to total Abeta ratio through clathrin-mediated endocytosis of gamma-secretase. Nat Commun 5:3386. doi: 10.1038/ncomms4386

332. Miller SE, Sahlender DA, Graham SC, Honing S, Robinson MS, Peden AA and Owen DJ (2011) The molecular basis for the endocytosis of small R-SNAREs by the clathrin adaptor CALM. Cell 147:1118-31. doi: 10.1016/j.cell.2011.10.038

333. Moreau K, Fleming A, Imarisio S, Lopez Ramirez A, Mercer JL, Jimenez-Sanchez M, Bento CF, Puri C, Zavodszky E, Siddiqi F, Lavau CP, Betton M, O'Kane CJ, Wechsler DS and Rubinsztein DC (2014) 
PICALM modulates autophagy activity and tau accumulation. Nat Commun 5:4998. doi: 10.1038/ncomms5998

334. Treusch S, Hamamichi S, Goodman JL, Matlack KE, Chung CY, Baru V, Shulman JM, Parrado A, Bevis BJ, Valastyan JS, Han H, Lindhagen-Persson M, Reiman EM, Evans DA, Bennett DA, Olofsson A, DeJager PL, Tanzi RE, Caldwell KA, Caldwell GA and Lindquist S (2011) Functional links between Abeta toxicity, endocytic trafficking, and Alzheimer's disease risk factors in yeast. Science 334:12415. doi: science.1213210 [pii]

\subsection{6/science. 1213210}

335. Ford MG, Pearse BM, Higgins MK, Vallis $Y$, Owen DJ, Gibson A, Hopkins CR, Evans PR and McMahon HT (2001) Simultaneous binding of Ptdlns(4,5)P2 and clathrin by AP180 in the nucleation of clathrin lattices on membranes. Science 291:1051-5. doi: 10.1126/science.291.5506.1051

336. Stahelin RV, Long F, Peter BJ, Murray D, De Camilli P, McMahon HT and Cho W (2003) Contrasting membrane interaction mechanisms of AP180 N-terminal homology (ANTH) and epsin Nterminal homology (ENTH) domains. J Biol Chem 278:28993-9. doi: 10.1074/jbc.M302865200

337. Cremona O, Di Paolo G, Wenk MR, Luthi A, Kim WT, Takei K, Daniell L, Nemoto Y, Shears SB, Flavell RA, McCormick DA and De Camilli P (1999) Essential role of phosphoinositide metabolism in synaptic vesicle recycling. Cell 99:179-88. doi: S0092-8674(00)81649-9 [pii]

338. Chen CK, Bregere C, Paluch J, Lu JF, Dickman DK and Chang KT (2014) Activity-dependent facilitation of Synaptojanin and synaptic vesicle recycling by the Minibrain kinase. Nat Commun 5:4246. doi: $10.1038 /$ ncomms5246

339. Xie J, Erneux C and Pirson I (2013) How does SHIP1/2 balance Ptdlns(3,4)P2 and does it signal independently of its phosphatase activity? Bioessays 35:733-43. doi: 10.1002/bies.201200168

340. Martin SB, Dowling AL, Lianekhammy J, Lott IT, Doran E, Murphy MP, Beckett TL, Schmitt FA and Head E (2014) Synaptophysin and synaptojanin-1 in Down syndrome are differentially affected by Alzheimer's disease. J Alzheimers Dis 42:767-75. doi: 10.3233/JAD-140795

341. Kang MS, Baek SH, Chun YS, Moore AZ, Landman N, Berman D, Yang HO, MorishimaKawashima M, Osawa S, Funamoto S, Ihara Y, Di Paolo G, Park JH, Chung S and Kim TW (2013) Modulation of lipid kinase PI4KIlalpha activity and lipid raft association of presenilin 1 underlies gamma-secretase inhibition by ginsenoside (20S)-Rg3. J Biol Chem 288:20868-82. doi: 10.1074/jbc.M112.445734

342. Pietri M, Dakowski C, Hannaoui S, Alleaume-Butaux A, Hernandez-Rapp J, Ragagnin A, Mouillet-Richard S, Haik S, Bailly Y, Peyrin JM, Launay JM, Kellermann O and Schneider B (2013) PDK1 decreases TACE-mediated alpha-secretase activity and promotes disease progression in prion and Alzheimer's diseases. Nat Med 19:1124-31. doi: 10.1038/nm.3302

343. Manterola L, Hernando-Rodriguez M, Ruiz A, Apraiz A, Arrizabalaga O, Vellon L, Alberdi E, Cavaliere F, Lacerda HM, Jimenez S, Parada LA, Matute C and Zugaza JL (2013) 1-42 beta-amyloid peptide requires PDK1/nPKC/Rac 1 pathway to induce neuronal death. Transl Psychiatry 3:e219. doi: 10.1038/tp.2012.147 
344. Morel E, Chamoun Z, Lasiecka ZM, Chan RB, Williamson RL, Vetanovetz C, Dall'Armi C, Simoes S, Point Du Jour KS, McCabe BD, Small SA and Di Paolo G (2013) Phosphatidylinositol-3phosphate regulates sorting and processing of amyloid precursor protein through the endosomal system. Nat Commun 4:2250. doi: 10.1038/ncomms3250

345. Wang L, Budolfson K and Wang F (2011) Pik3c3 deletion in pyramidal neurons results in loss of synapses, extensive gliosis and progressive neurodegeneration. Neuroscience 172:427-42. doi: 10.1016/j.neuroscience.2010.10.035

346. Quadri M, Fang M, Picillo M, Olgiati S, Breedveld GJ, Graafland J, Wu B, Xu F, Erro R, Amboni M, Pappata S, Quarantelli M, Annesi G, Quattrone A, Chien HF, Barbosa ER, International Parkinsonism Genetics N, Oostra BA, Barone P, Wang J and Bonifati V (2013) Mutation in the SYNJ1 gene associated with autosomal recessive, early-onset Parkinsonism. Hum Mutat 34:1208-15. doi: 10.1002/humu.22373

347. Olgiati S, De Rosa A, Quadri M, Criscuolo C, Breedveld GJ, Picillo M, Pappata S, Quarantelli M, Barone P, De Michele G and Bonifati V (2014) PARK20 caused by SYNJ1 homozygous Arg258GIn mutation in a new Italian family. Neurogenetics 15:183-8. doi: 10.1007/s10048-014-0406-0

348. Winkler S, Vollstedt EJ, Kasten M, Alvarez-Fischer D, Klein C and Lohmann K (2014) The recurrent mutation Arg258GIn in SYNJ1 (PARK20) is not a common cause of Parkinson's disease. J Neurol 261:833-4. doi: 10.1007/s00415-014-7306-y

349. Krebs CE, Karkheiran S, Powell JC, Cao M, Makarov V, Darvish H, Di Paolo G, Walker RH, Shahidi GA, Buxbaum JD, De Camilli P, Yue Z and Paisan-Ruiz C (2013) The Sac1 domain of SYNJ1 identified mutated in a family with early-onset progressive Parkinsonism with generalized seizures. Hum Mutat 34:1200-7. doi: 10.1002/humu.22372

350. Dyment DA, Smith AC, Humphreys P, Schwartzentruber J, Beaulieu CL, Consortium FC, Bulman DE, Majewski J, Woulfe J, Michaud J and Boycott KM (2014) Homozygous nonsense mutation in SYNJ1 associated with intractable epilepsy and tau pathology. Neurobiol Aging. doi: 10.1016/j.neurobiolaging.2014.09.005

351. Dyment DA, Tetreault M, Beaulieu CL, Hartley T, Ferreira P, Chardon JW, Marcadier J, Sawyer SL, Mosca SJ, Innes AM, Parboosingh JS, Bulman DE, Schwartzentruber J, Majewski J, Tarnopolsky M, Boycott KM, Consortium FC and Care4Rare C (2014) Whole-exome sequencing broadens the phenotypic spectrum of rare pediatric epilepsy: a retrospective study. Clin Genet. doi: 10.1111/cge.12464

352. Fabelo N, Martin V, Santpere G, Marin R, Torrent L, Ferrer I and Diaz M (2011) Severe alterations in lipid composition of frontal cortex lipid rafts from Parkinson's disease and incidental Parkinson's disease. Mol Med 17:1107-18. doi: 10.2119/molmed.2011.00119

353. Drouet V and Lesage S (2014) Synaptojanin 1 Mutation in Parkinson's Disease Brings Further Insight into the Neuropathological Mechanisms. Biomed Res Int 2014:289728. doi: $10.1155 / 2014 / 289728$ 
354. Lopez LM, Harris SE, Luciano M, Liewald D, Davies G, Gow AJ, Tenesa A, Payton A, Ke X, Whalley L, Fox H, Haggerty P, Ollier W, Pickles A, Porteous DJ, Horan MA, Pendleton N, Starr JM and Deary IJ (2012) Evolutionary conserved longevity genes and human cognitive abilities in elderly cohorts. Eur J Hum Genet 20:341-7. doi: 10.1038/ejhg.2011.201

355. Luciano M, Lopez LM, de Moor MH, Harris SE, Davies G, Nutile T, Krueger RF, Esko T, Schlessinger D, Toshiko T, Derringer JL, Realo A, Hansell NK, Pergadia ML, Pesonen AK, Sanna S, Terracciano A, Madden PA, Penninx B, Spinhoven P, Hartman CA, Oostra BA, Janssens AC, Eriksson JG, Starr JM, Cannas A, Ferrucci L, Metspalu A, Wright MJ, Heath AC, van Duijn CM, Bierut LJ, Raikkonen K, Martin NG, Ciullo M, Rujescu D, Boomsma DI and Deary IJ (2012) Longevity candidate genes and their association with personality traits in the elderly. Am J Med Genet B Neuropsychiatr Genet 159B:192-200. doi: 10.1002/ajmg.b.32013

356. Manji SS, Williams LH, Miller KA, Ooms LM, Bahlo M, Mitchell CA and Dahl HH (2011) A mutation in synaptojanin 2 causes progressive hearing loss in the ENU-mutagenised mouse strain Mozart. PLoS One 6:e17607. doi: 10.1371/journal.pone.0017607

357. Hatano Y, Li Y, Sato K, Asakawa S, Yamamura Y, Tomiyama H, Yoshino H, Asahina M, Kobayashi S, Hassin-Baer S, Lu CS, Ng AR, Rosales RL, Shimizu N, Toda T, Mizuno Y and Hattori N (2004) Novel PINK1 mutations in early-onset parkinsonism. Ann Neurol 56:424-7. doi: 10.1002/ana.20251

358. Rohe CF, Montagna P, Breedveld G, Cortelli P, Oostra BA and Bonifati V (2004) Homozygous PINK1 C-terminus mutation causing early-onset parkinsonism. Ann Neurol 56:427-31. doi: 10.1002/ana.20247

359. Valente EM, Abou-Sleiman PM, Caputo V, Muqit MM, Harvey K, Gispert S, Ali Z, Del Turco D, Bentivoglio AR, Healy DG, Albanese A, Nussbaum R, Gonzalez-Maldonado R, Deller T, Salvi S, Cortelli P, Gilks WP, Latchman DS, Harvey RJ, Dallapiccola B, Auburger G and Wood NW (2004) Hereditary early-onset Parkinson's disease caused by mutations in PINK1. Science 304:1158-60. doi: 10.1126/science.1096284

360. Valente EM, Salvi S, lalongo T, Marongiu R, Elia AE, Caputo V, Romito L, Albanese A, Dallapiccola B and Bentivoglio AR (2004) PINK1 mutations are associated with sporadic early-onset parkinsonism. Ann Neurol 56:336-41. doi: 10.1002/ana.20256

361. Nair VD, Olanow CW and Sealfon SC (2003) Activation of phosphoinositide 3-kinase by D2 receptor prevents apoptosis in dopaminergic cell lines. Biochem J 373:25-32. doi: 10.1042/BJ20030017

362. Hardingham GE (2009) Coupling of the NMDA receptor to neuroprotective and neurodestructive events. Biochem Soc Trans 37:1147-60. doi: 10.1042/BST0371147

363. Yatsu FM and Moss SA (1971) Brain lipid changes following hypoxia. Stroke 2:587-93.

364. Lin TN, Liu TH, Xu J, Hsu CY and Sun GY (1991) Brain polyphosphoinositide metabolism during focal ischemia in rat cortex. Stroke 22:495-8. 
365. Bralet J, Beley P, Jemaa R, Bralet AM and Beley A (1987) Lipid metabolism, cerebral metabolic rate, and some related enzyme activities after brain infarction in rats. Stroke 18:418-25.

366. Koutouzov S, Marche P, Girard A and Meyer P (1983) Altered turnover of polyphosphoinositides in the erythrocyte membrane of the spontaneously hypertensive rat. Hypertension 5:409-14.

367. Furuta $Y$, Uehara $T$ and Nomura $Y$ (2003) Correlation between delayed neuronal cell death and selective decrease in phosphatidylinositol 4-kinase expression in the CA1 subfield of the hippocampus after transient forebrain ischemia. J Cereb Blood Flow Metab 23:962-71. doi: 10.1097/01.WCB.0000073948.29308.F8

368. Abe E, Fujiki M, Nagai Y, Shiqi K, Kubo T, Ishii K, Abe T and Kobayashi H (2010) The phosphatidylinositol-3 kinase/Akt pathway mediates geranylgeranylacetone-induced neuroprotection against cerebral infarction in rats. Brain Res 1330:151-7. doi: 10.1016/j.brainres.2010.02.074

369. Brennan-Minnella AM, Shen Y, El-Benna J and Swanson RA (2013) Phosphoinositide 3-kinase couples NMDA receptors to superoxide release in excitotoxic neuronal death. Cell Death Dis 4:e580. doi: 10.1038/cddis.2013.111

370. Chan CB, Liu X, Pradoldej S, Hao C, An J, Yepes M, Luo HR and Ye K (2011) Phosphoinositide 3-kinase enhancer regulates neuronal dendritogenesis and survival in neocortex. J Neurosci 31:808392. doi: 10.1523/JNEUROSCI.1129-11.2011

371. Endo H, Nito C, Kamada H, Yu F and Chan PH (2006) Akt/GSK3beta survival signaling is involved in acute brain injury after subarachnoid hemorrhage in rats. Stroke 37:2140-6. doi: 10.1161/01.STR.0000229888.55078.72

372. Jackson SP, Schoenwaelder SM, Goncalves I, Nesbitt WS, Yap CL, Wright CE, Kenche V, Anderson KE, Dopheide SM, Yuan Y, Sturgeon SA, Prabaharan H, Thompson PE, Smith GD, Shepherd PR, Daniele N, Kulkarni S, Abbott B, Saylik D, Jones C, Lu L, Giuliano S, Hughan SC, Angus JA, Robertson AD and Salem HH (2005) PI 3-kinase p110beta: a new target for antithrombotic therapy. Nat Med 11:507-14. doi: 10.1038/nm1232

373. Jin R, Yu S, Song Z, Quillin JW, Deasis DP, Penninger JM, Nanda A, Granger DN and Li G (2010) Phosphoinositide 3-kinase-gamma expression is upregulated in brain microglia and contributes to ischemia-induced microglial activation in acute experimental stroke. Biochem Biophys Res Commun 399:458-64. doi: 10.1016/j.bbrc.2010.07.116

374. Katakowski M, Zhang ZG, Chen J, Zhang R, Wang Y, Jiang H, Zhang L, Robin A, Li Y and Chopp M (2003) Phosphoinositide 3-kinase promotes adult subventricular neuroblast migration after stroke. J Neurosci Res 74:494-501. doi: 10.1002/jnr.10775

375. Kilic E, Kilic U, Wang Y, Bassetti CL, Marti HH and Hermann DM (2006) The phosphatidylinositol-3 kinase/Akt pathway mediates VEGF's neuroprotective activity and induces blood brain barrier permeability after focal cerebral ischemia. FASEB J 20:1185-7. doi: 10.1096/fj.054829fje 
376. Kim S, Lee KY, Koh SH, Park HH, Yu HJ and Lee YJ (2012) Role of the phosphatidylinositol 3kinase and extracellular signal-regulated kinase pathways in the neuroprotective effects of cilnidipine against hypoxia in a primary culture of cortical neurons. Neurochem Int 61:1172-82. doi: 10.1016/j.neuint.2012.08.010

377. Tu WJ, Liu XY, Dong H, Yu Y, Wang $Y$ and Chen H (2014) Phosphatidylinositol-3,4,5trisphosphate 5-phosphatase 1: a meaningful and independent marker to predict stroke in the Chinese population. J Mol Neurosci 52:507-14. doi: 10.1007/s12031-013-0206-2

378. Toschi V, Motta A, Castelli C, Paracchini ML, Zerbi D and Gibelli A (1998) High prevalence of antiphosphatidylinositol antibodies in young patients with cerebral ischemia of undetermined cause. Stroke 29:1759-64. 
Table 1

Disease

Protein

Lipid

$P I(4,5) P_{2}$ imbalances

Chronic pain

PIPK5K1C

$\mathrm{PI}(4,5) \mathrm{P}_{2}$

PLCB3

$\mathrm{PI}(4,5) \mathrm{P}_{2}$

Friedreich's ataxia

PIP5K1B

$\mathrm{PI}(4,5) \mathrm{P}_{2}$

Lethal muscle contractural

syndrome type 3

PIPK5K1C

$\mathrm{PI}(4,5) \mathrm{P}_{2}$

Charcot-Marie-Tooth disease

Dynamin

$\mathrm{PI}(4,5) \mathrm{P}_{2}$

(intermediate form and $\mathrm{CMT2B}$ )

OCRL Lowe's disease

OCRL1

$\mathrm{PI}(4,5) \mathrm{P}_{2}$

Dent's disease

OCRL1

$\mathrm{PI}(4,5) \mathrm{P}_{2}$

\section{Channelopathies}

Epilepsy

KNVQ channel

$\mathrm{PI}(4,5) \mathrm{P}_{2}$

Andersen-Tawil syndrome

KCNJ2 channel

$\mathrm{PI}(4,5) \mathrm{P}_{2}$

Charcot-Marie-Tooth type $2 \mathrm{C}$

TRPV4 channel

$\mathrm{PI}(4,5) \mathrm{P}_{2}$

Mucolipidosis type IV

TRPML1 channel

$\mathrm{PI}(3,5) \mathrm{P}_{2}$

Defective PI3K pathways

Multiple sclerosis

PIK3G

$\mathrm{PI}(3,4,5) \mathrm{P}_{3}$

Hemimegalencephaly

PIK3CA

$\mathrm{PI}(3,4,5) \mathrm{P}_{3}$

AKT3

$\mathrm{PI}(3,4,5) \mathrm{P}_{3}$

Megalencephaly

PIK3R2

$\mathrm{PI}(3,4,5) \mathrm{P}_{3}$

PIK3CA

$\mathrm{PI}(3,4,5) \mathrm{P}_{3}$

PTEN

$\mathrm{PI}(3,4,5) \mathrm{P}_{3}$

AKT3

$\mathrm{PI}(3,4,5) \mathrm{P}_{3}$

Microcephaly

INPP4A

$\mathrm{PI}(3,4) \mathrm{P}_{2}$

PTEN hamartoma tumour

syndromes (PHTS)

PTEN

$\mathrm{PI}(3,4,5) \mathrm{P}_{3}$

Brain cancers

PTEN

$\mathrm{PI}(3,4,5) \mathrm{P}_{3}$

PIK3CA

$\mathrm{PI}(3,4,5) \mathrm{P}_{3}$

X-linked recessive

centronuclear myopathy

MTM1

$\mathrm{PI}(3,5) \mathrm{P}_{2}$

CMT4B2

MTMR2

$\mathrm{PI}(3,5) \mathrm{P}_{2}$

CMT4J

Sac3/FIG4 
Table 1

Yunis-Varón syndrome

Amytropic lateral sclerosis

Joubert's ciliopathy

MORM ciliopathy

Autism spectrum

Alzheimer's disease

Parkinson's disease
Sac3/FIG4

Sac3/FIG4

INPP5E

INPP5E

PTEN

PIK3CA

PIK3C2A

PIK3R2

PICALM

PI4K2A

Synaptojanin 1

PDK1

VPS34

Synaptojanin 2
$\mathrm{PI}(3,5) \mathrm{P}_{2}$

$\mathrm{PI}(3,5) \mathrm{P}_{2}$

$\mathrm{PI}(3,5) \mathrm{P}_{2} / \mathrm{PI}(3,4,5) \mathrm{P}_{3}$

$\mathrm{PI}(3,5) \mathrm{P}_{2} / \mathrm{PI}(3,4,5) \mathrm{P}_{3}$

$\mathrm{PI}(3,4,5) \mathrm{P}_{3}$

$\mathrm{PI}(3,4,5) \mathrm{P}_{3}$

$\mathrm{PI}(3,4) \mathrm{P}_{2}$

$\mathrm{PI}(3,4,5) \mathrm{P}_{3}$

PI4P

$\mathrm{PI}(4,5) \mathrm{P}_{2}$

$\mathrm{PI}(3,4,5) \mathrm{P}_{3}$

PI3P

$\mathrm{PI}(4,5) \mathrm{P}_{2}$ 
Figure 1
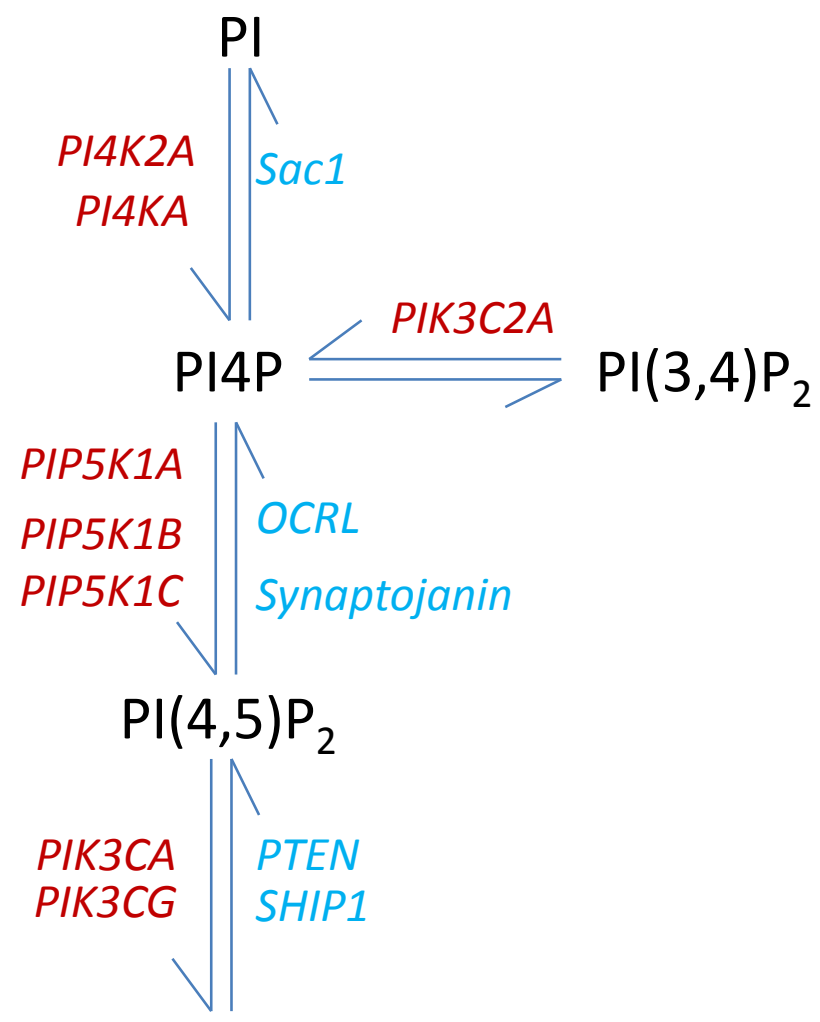

$$
\mathrm{PI}(3,4,5) \mathrm{P}_{3}
$$

INPP5B, INPP5E

INPP4A, INPP4B

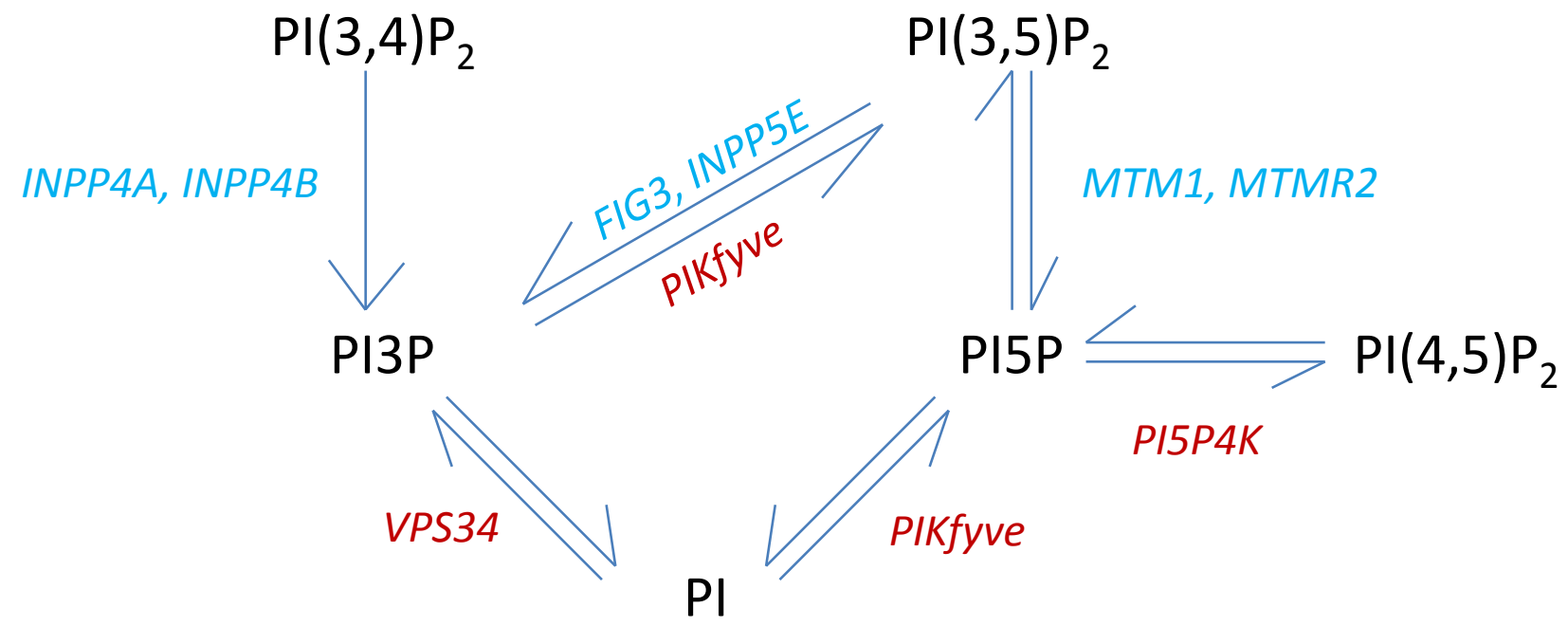


Figure 2

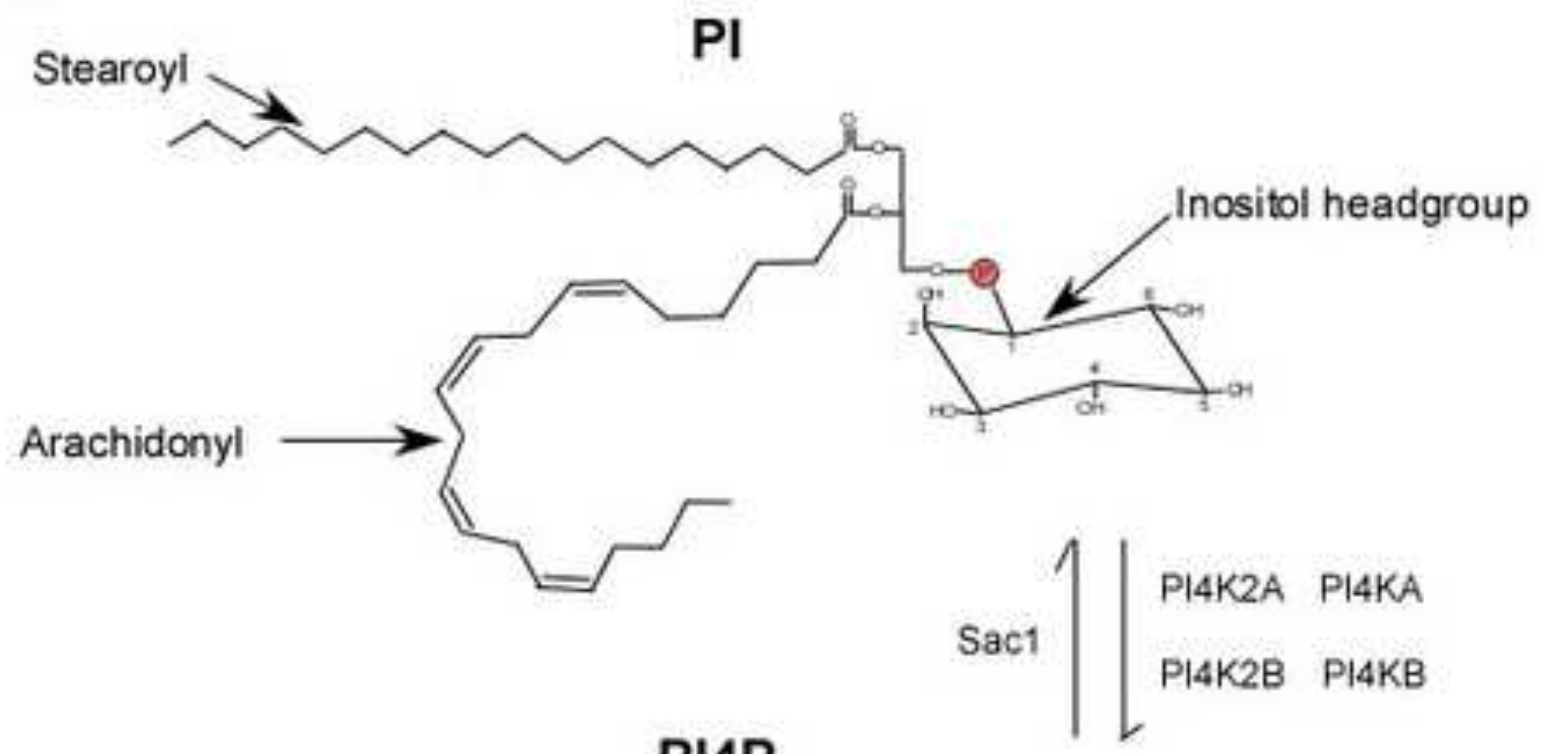

PI4P
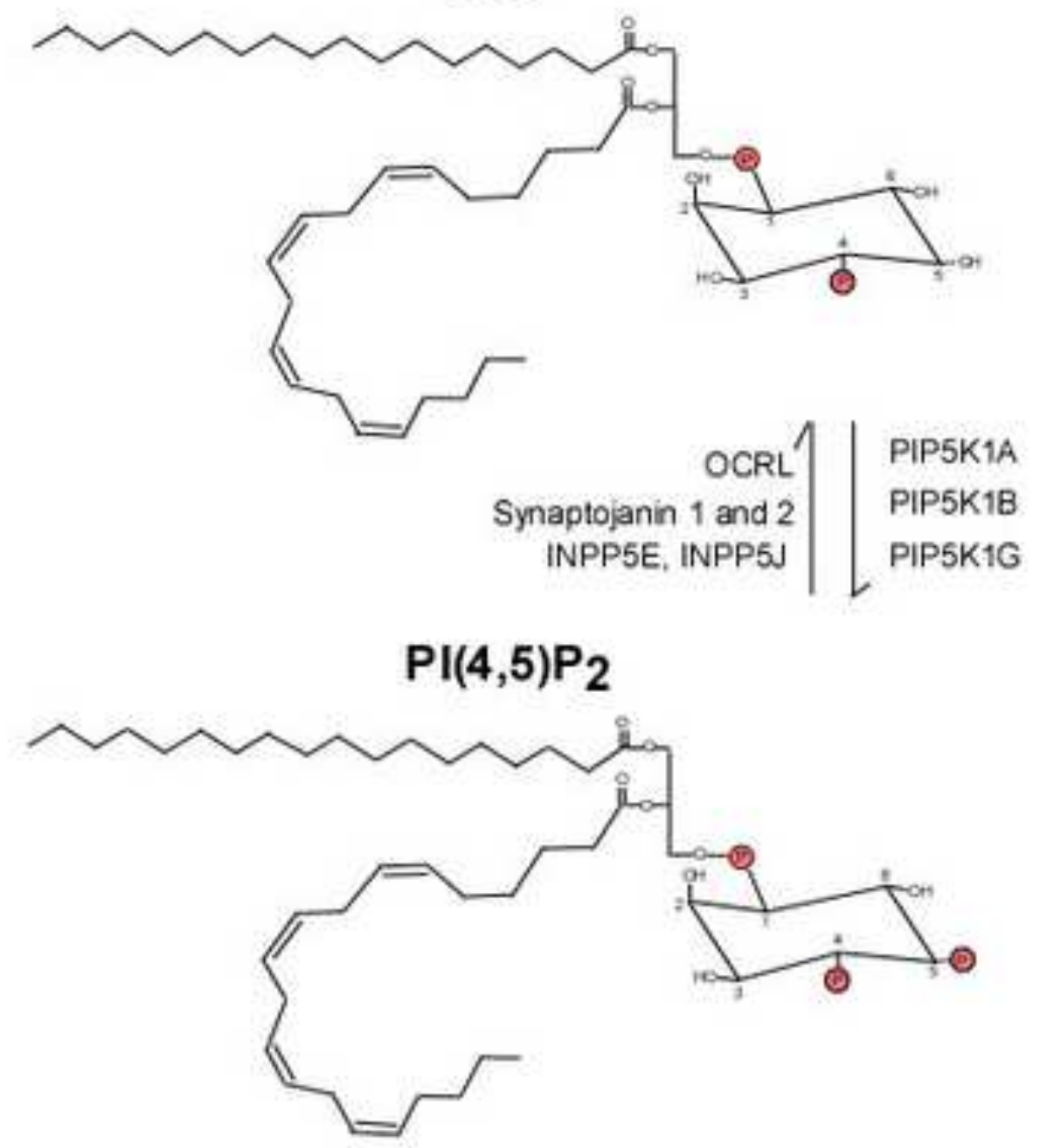
${ }^{*}$ Conflict of Interest
Click here to download Conflict of Interest: Conflict of interest statement.docx

${ }^{*}$ Conflict of Interest
Click here to download Conflict of Interest: Conflict of interest statement.docx

Click here to download Conflict of Interest: Conflict of interest statement.docx

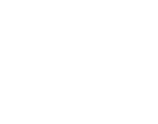
(

(1)

(1)

(1)

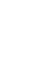

(1)

(1)

(1)

.

.

.

.

.

.

.

.

.

.

.

.

.

.

.

.

.

.

.

.

. 